\title{
اللغة العربية وعنف اللسان في الفضائيات العربية \\ دراسة استقرائية قيمية
}

د. نصير صالح بوعلي

أستاذ الإعلا م المساعد بكلية الاتصال

$$
\text { جامعة الشارقة }
$$

\section{مستخلص}

فسـت الفضائيـات مجـالا واســعا ورحبـا للَهــات المحلّية على حسـاب اللغة العربية

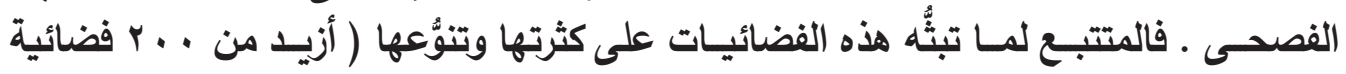

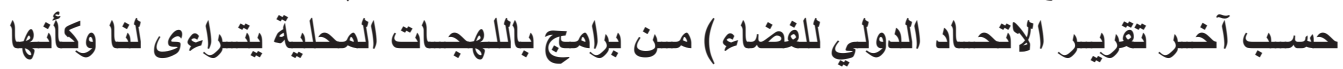

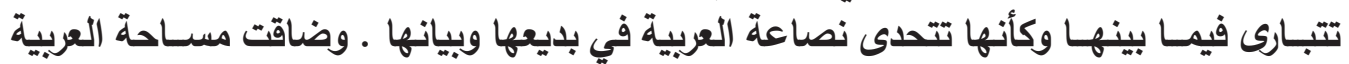

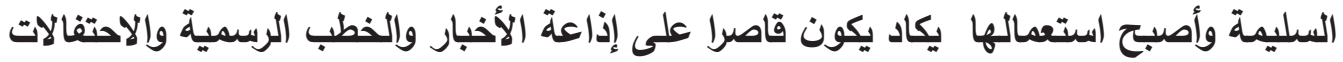

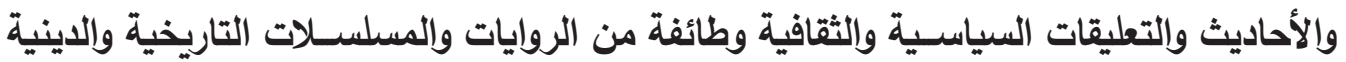

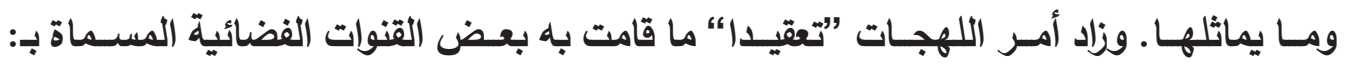

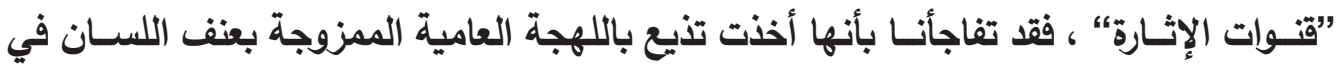

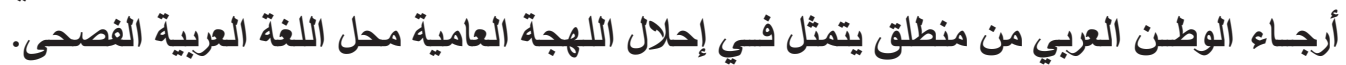

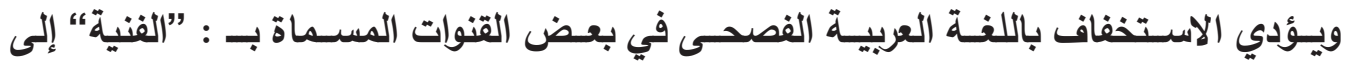

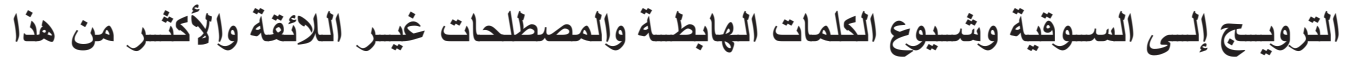

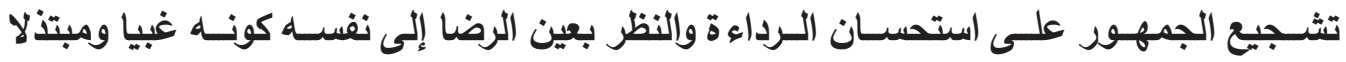

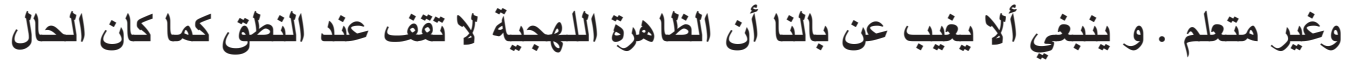

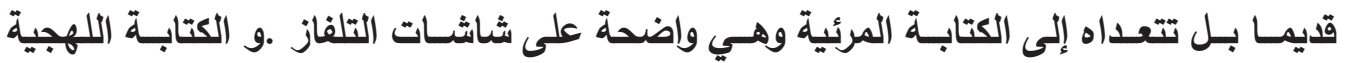

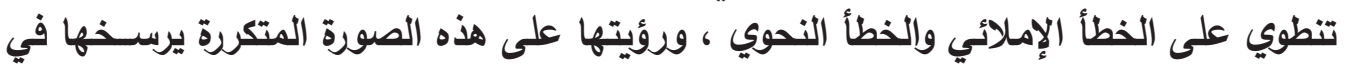

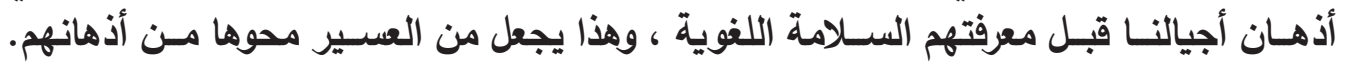

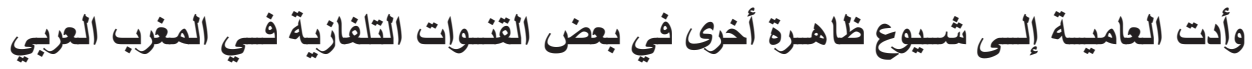

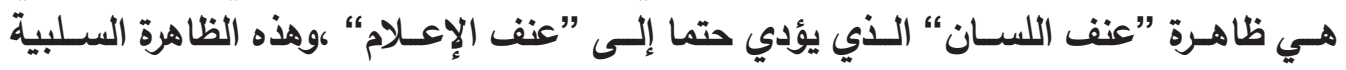




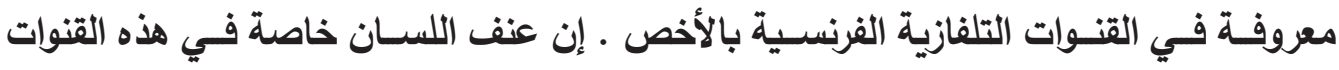

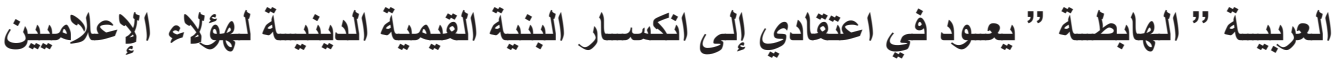

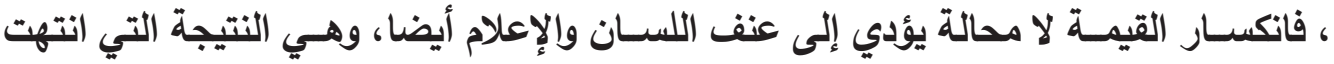

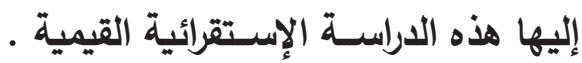

\section{Abstract}

This study aimed at identifying the effect of violence on speech disorders concerning Arab Broadcasting . Language is a pot of thought and a mirror of human civilization and communication tool, but the Arabic language is suffering a lot of extraneous terms them, particularly through the media. This study attempts to answer the following question: Is the phenomenon of linguistic duality in the Media reflected negatively on the rules of the classical language? The study deals with the explanation and interpretation of the phenomenon that has become slang exist in our Media More. And the study suggests reconsideration of the value in the Media, hence the problem will be resolved.

المدخل

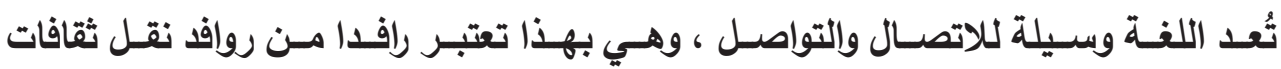

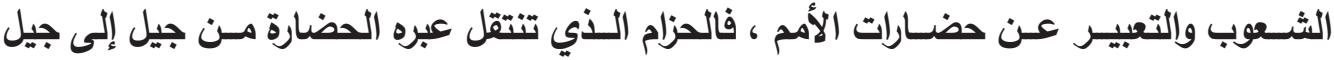

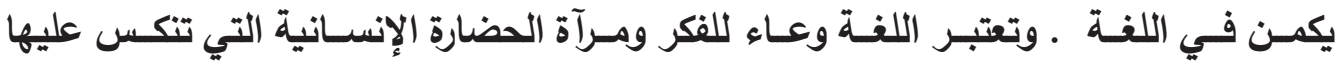

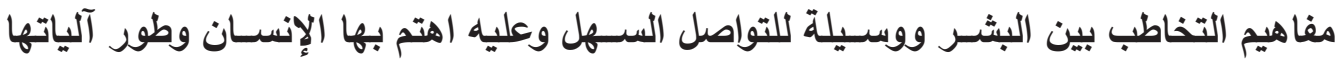

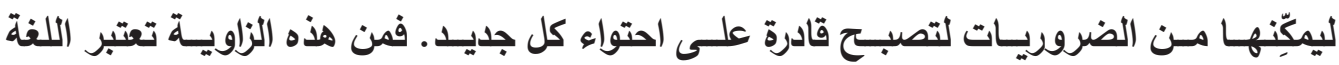

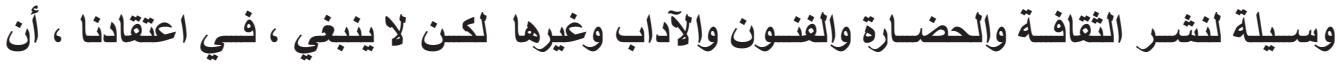

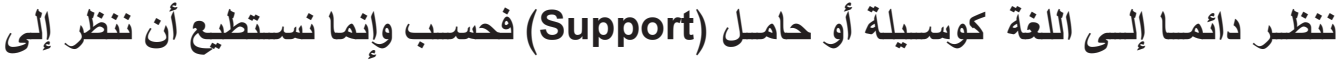

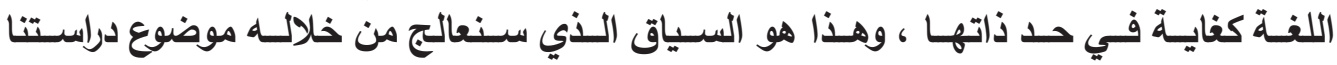

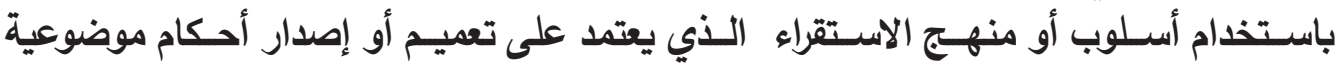

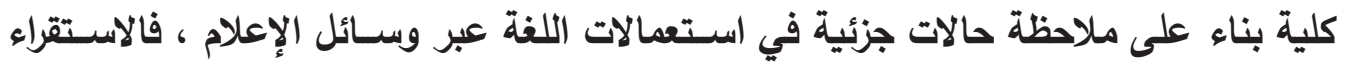

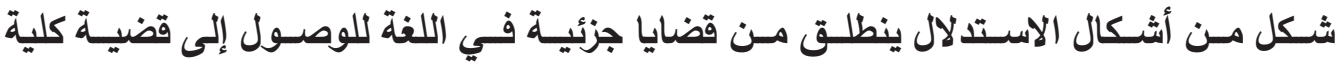

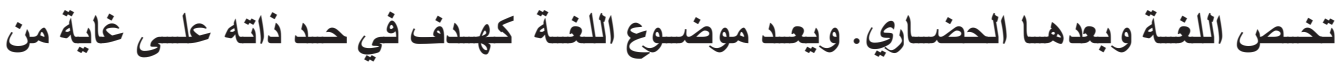

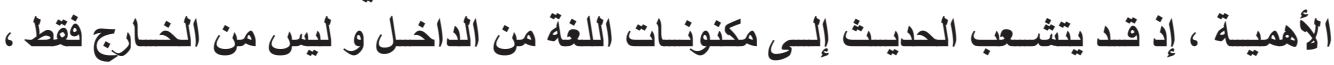

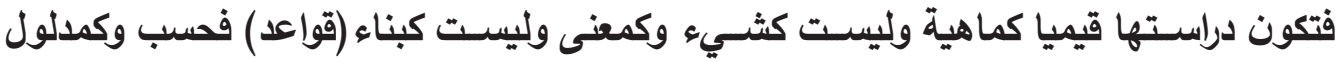




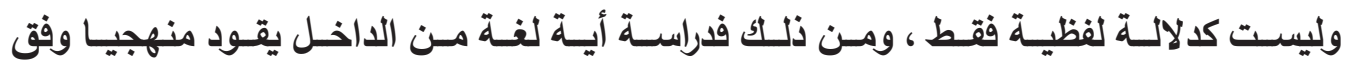

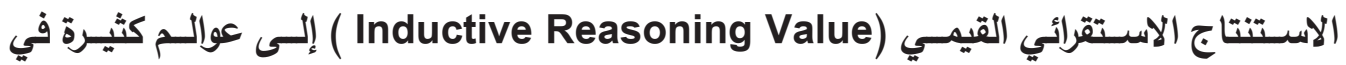

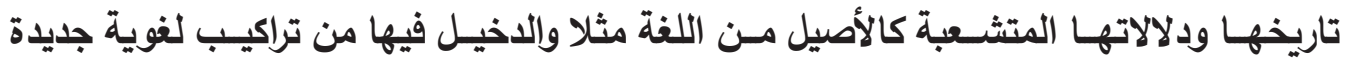

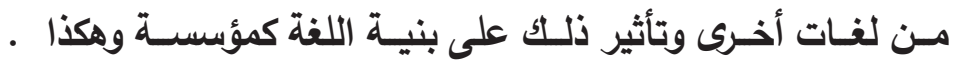

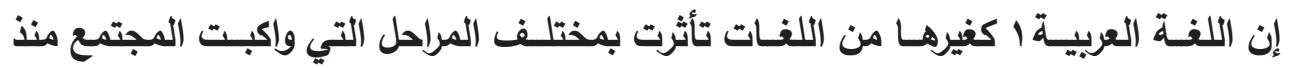

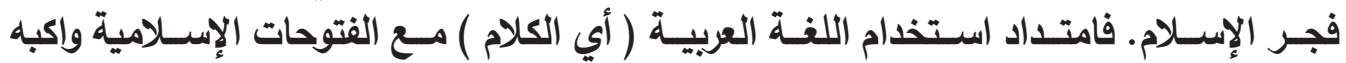

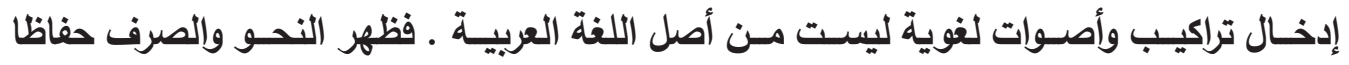

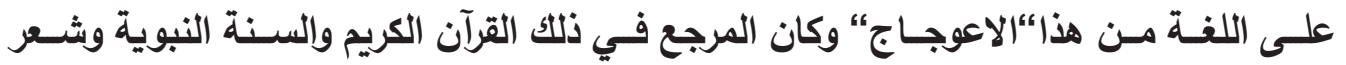

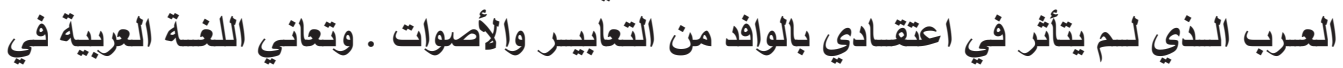

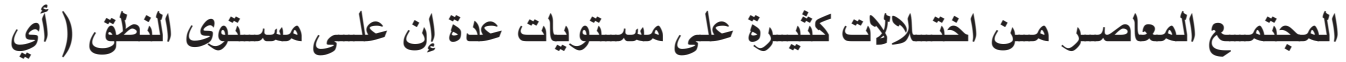

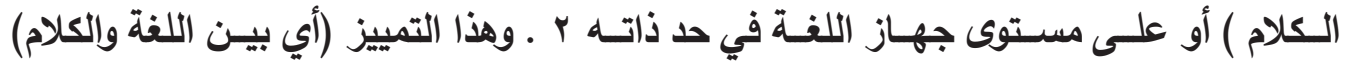

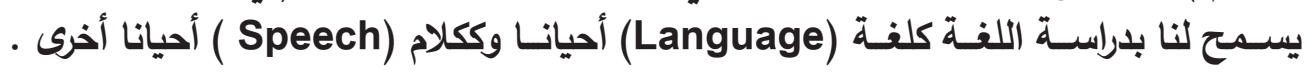

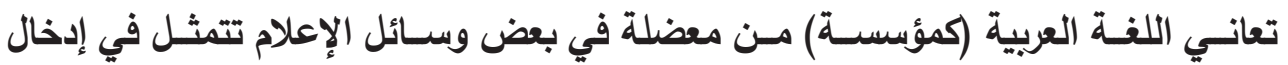

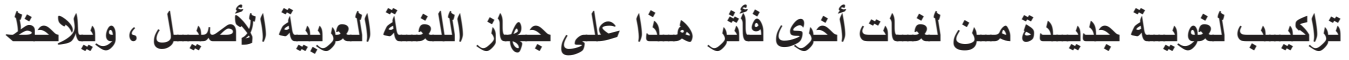

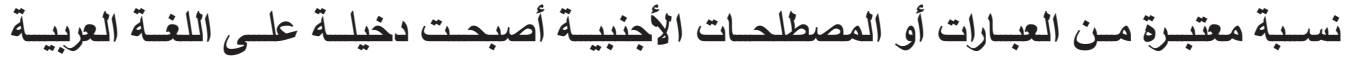

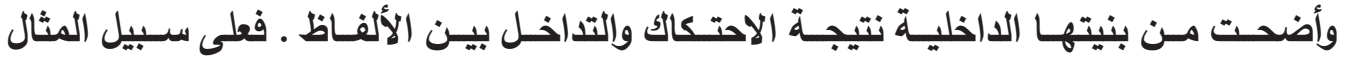

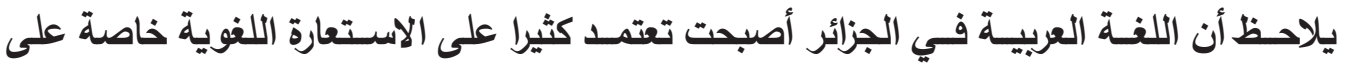

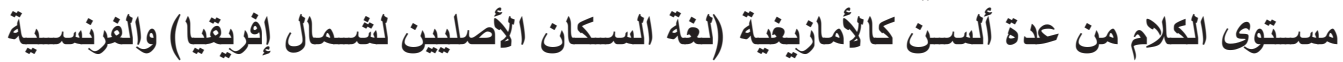

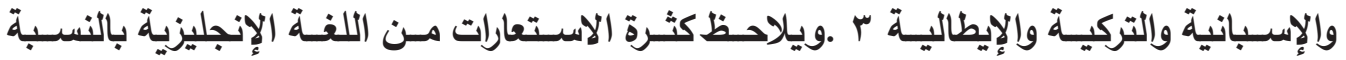

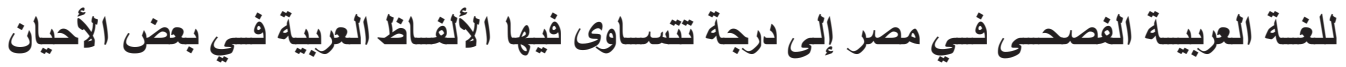

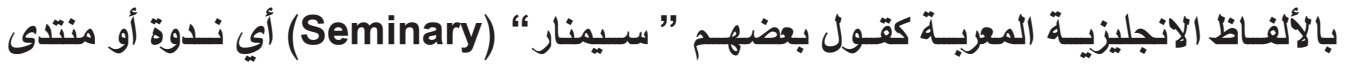

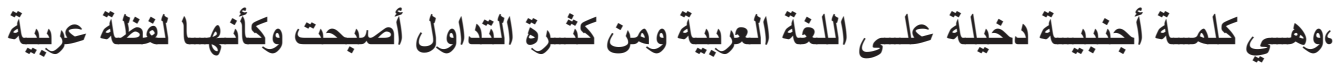

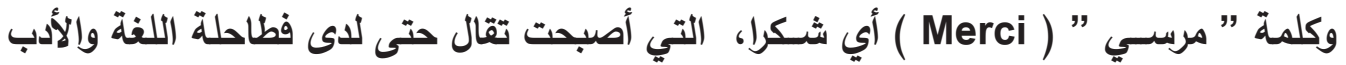

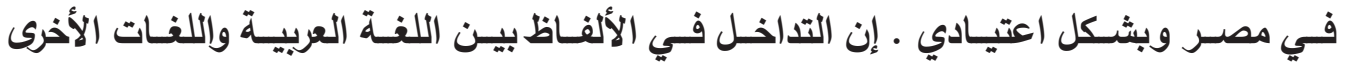

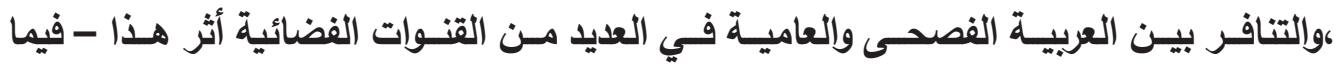

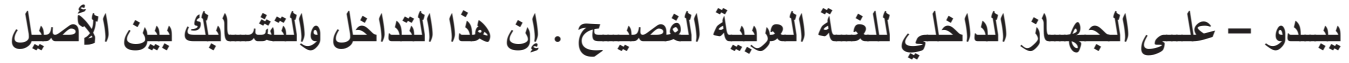

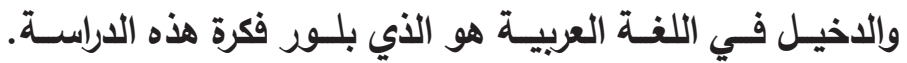




\section{أولا - مشكلة الدراسة}

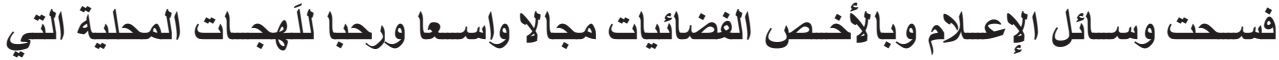

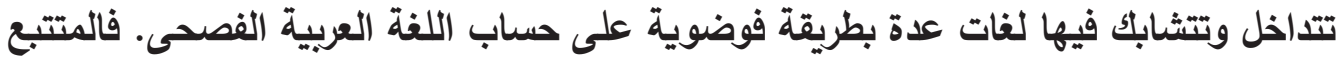

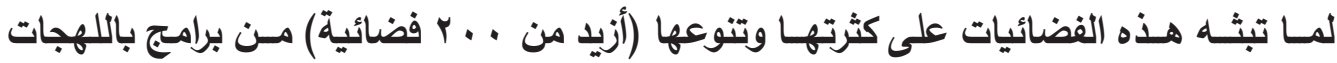

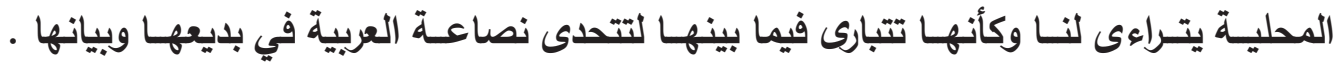

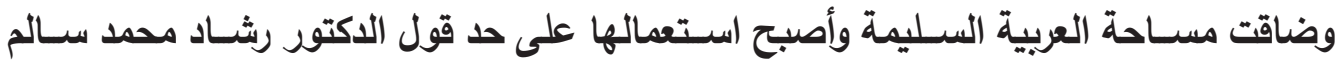

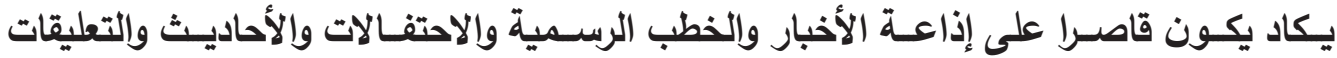

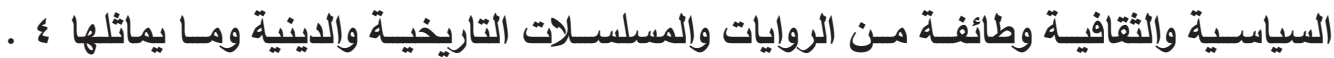

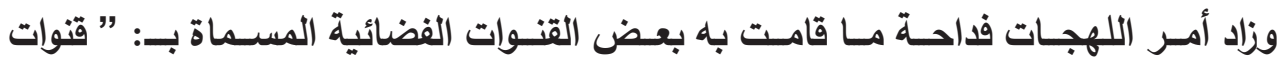

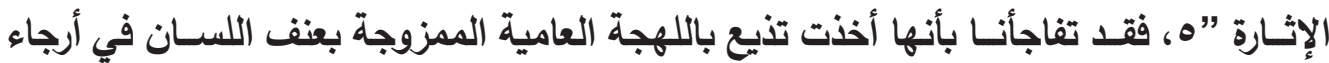

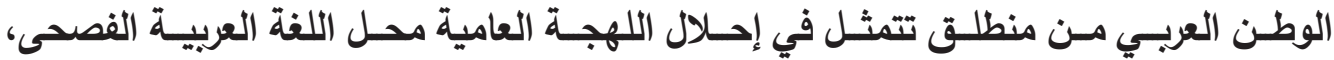

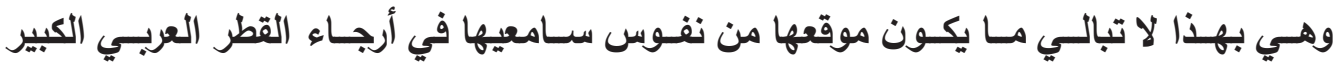

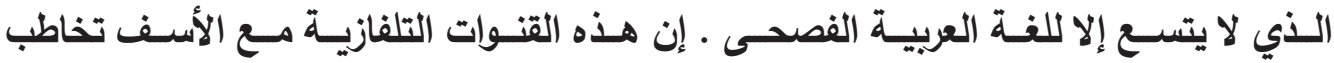

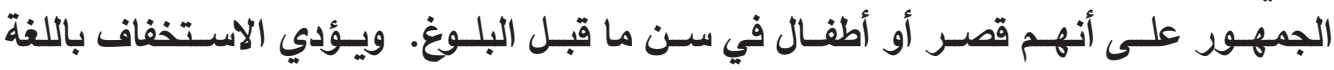

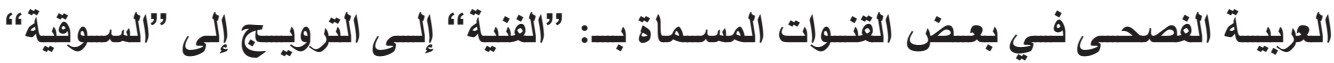

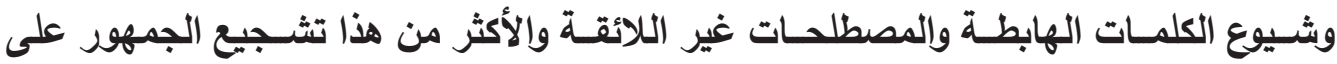

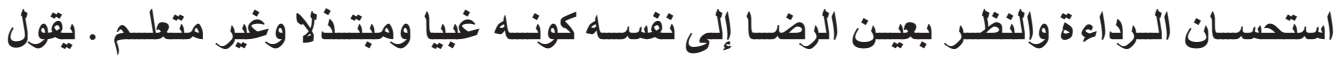

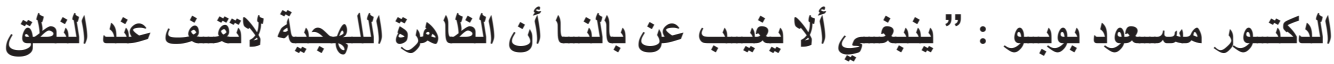

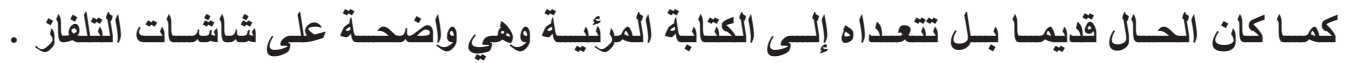

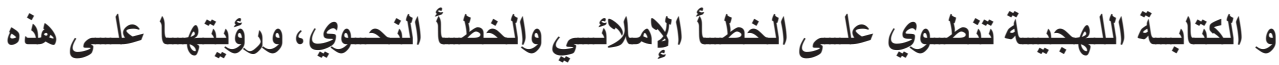

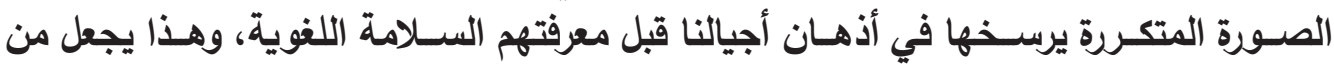

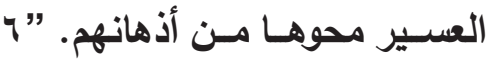

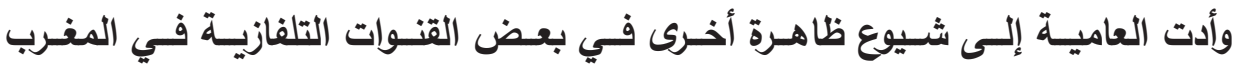

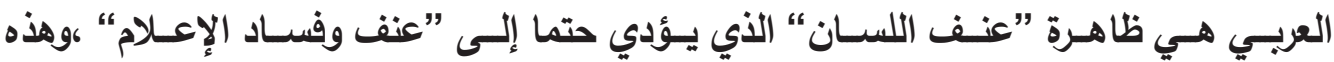

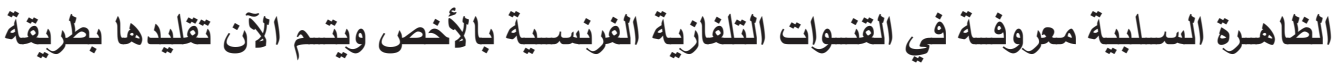

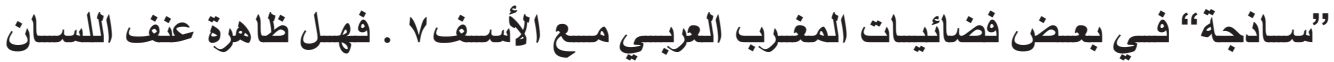

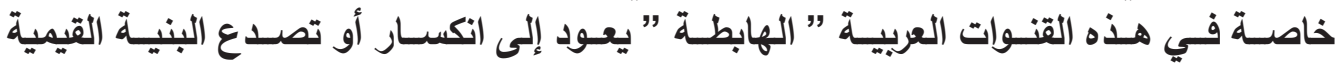




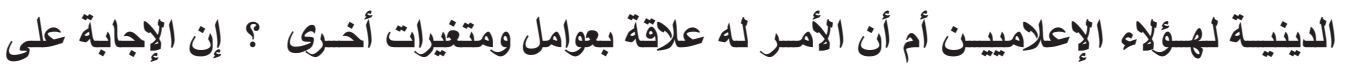

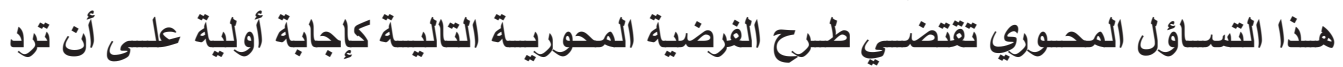

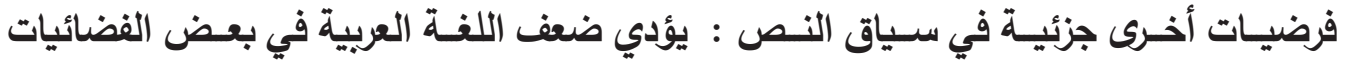

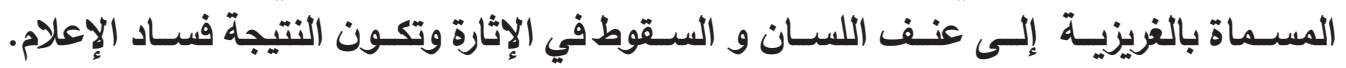

وسنحاول الإجابة على التساؤل المحوري للبحث واختبار فرضية الدراسة وفق الترتيب المنطقي للاراسة ـ ولكن قبل ذلك من الضروري تعريف مفا هيم الدراسة اصطلاحيا حسب أهميتها في الموضوع.

\section{ثانيا - مفاهيم الدراسة}

ا - تعريف اللغة

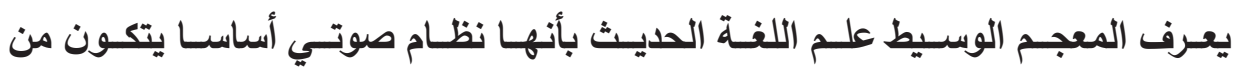

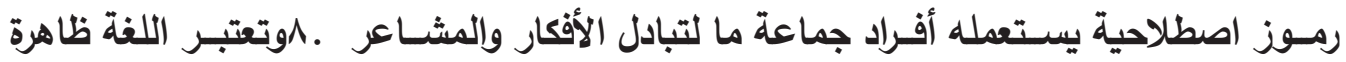

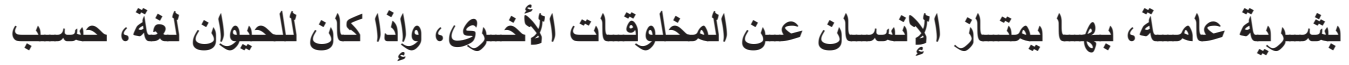

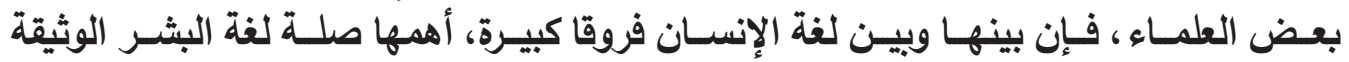

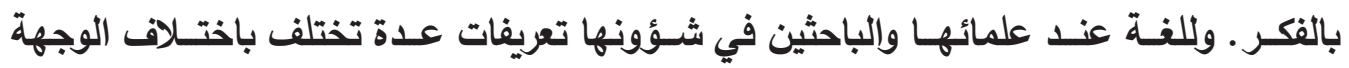

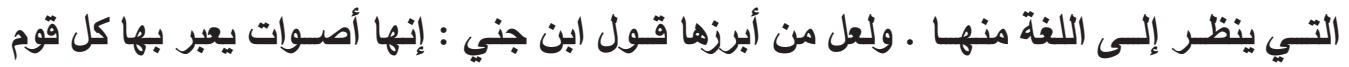

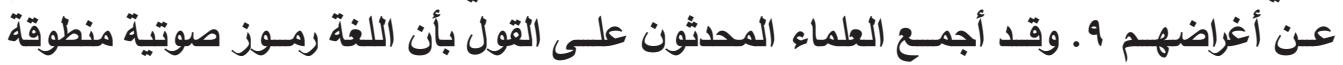

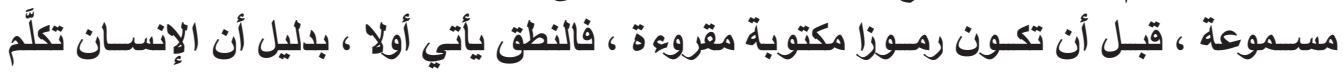

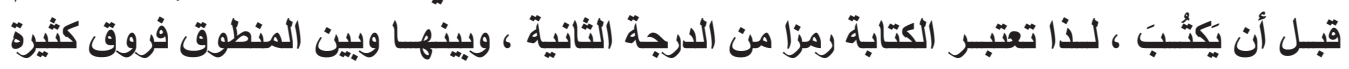

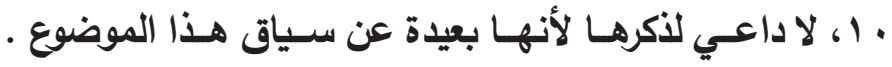

\section{r- اللغة الإعلامية}

هنـاك ثلاثـة مسـتويات للتعبيـر اللفـوي. المسـتوى الأول - المسـتوى التذوقي الفني

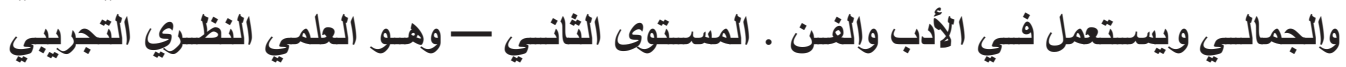

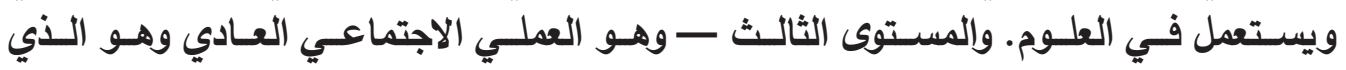

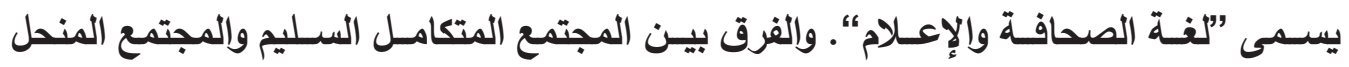

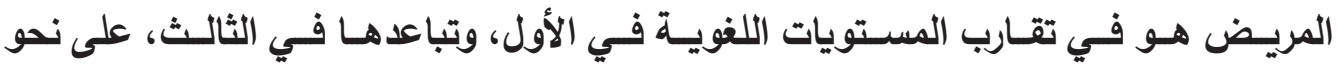

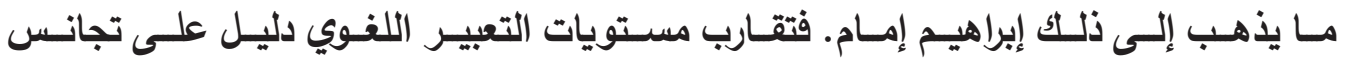

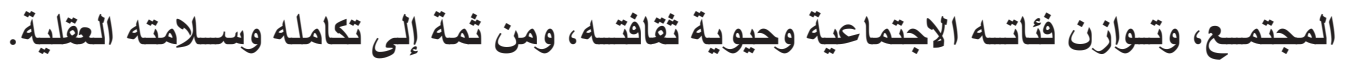




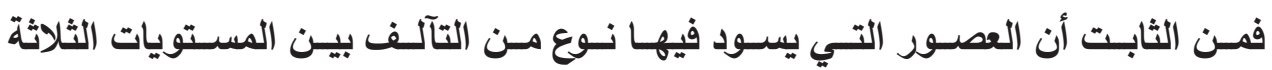

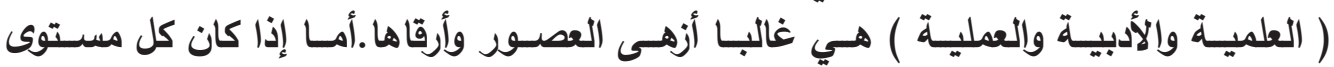

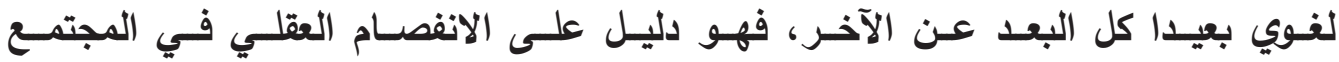

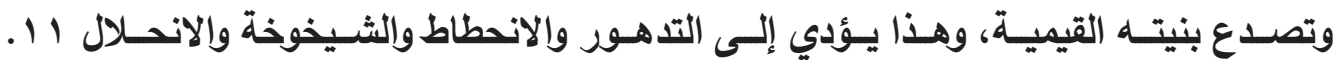

\section{r- عنف اللسان}

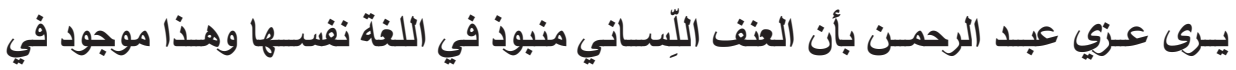

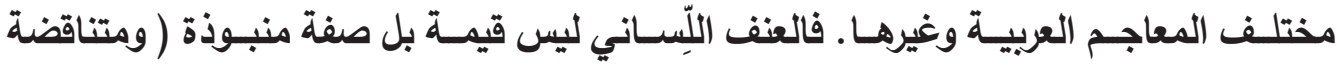

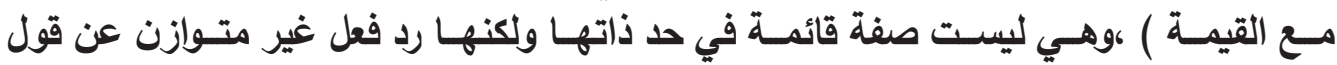

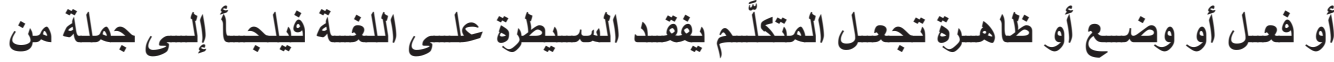

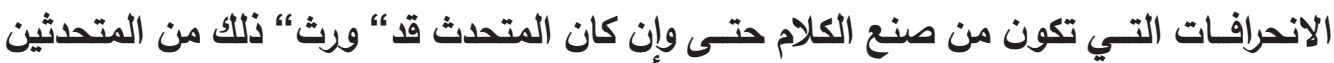

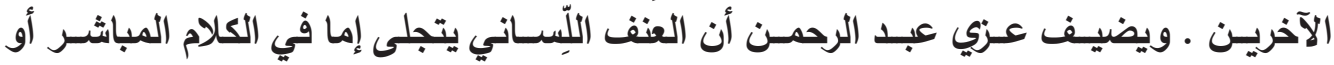

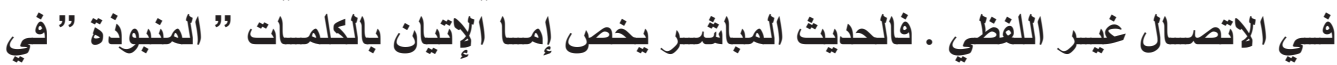

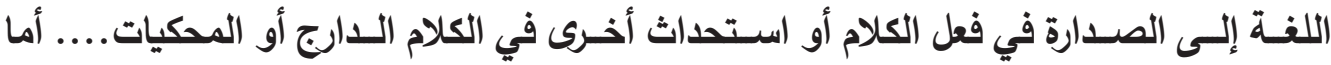

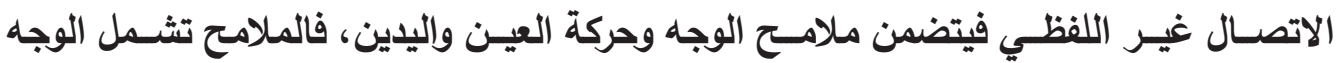

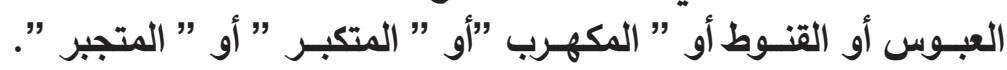

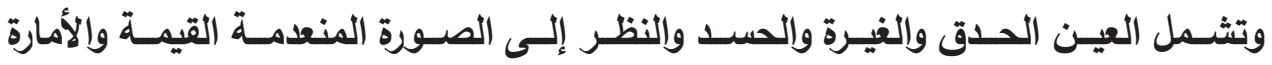

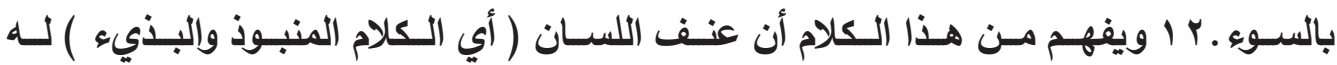

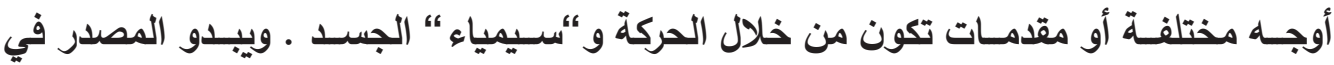

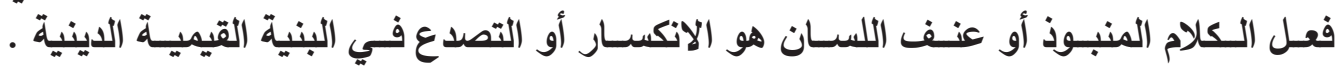

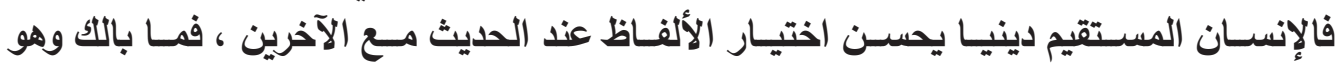

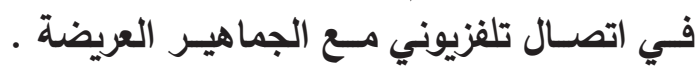

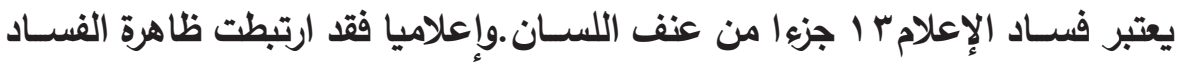

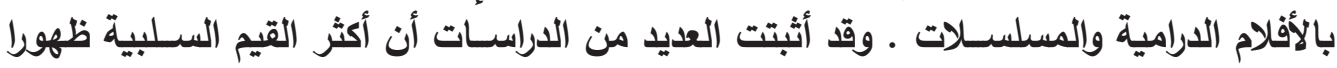

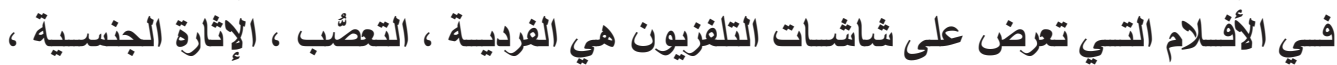

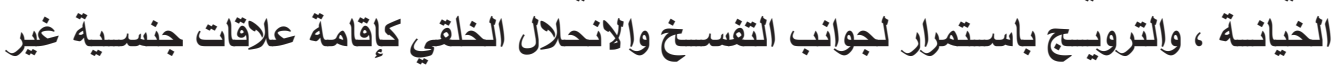

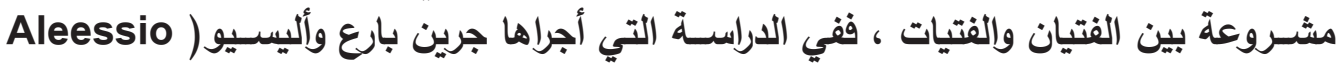
البانبان - Greenberg

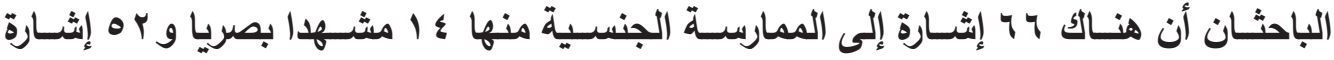

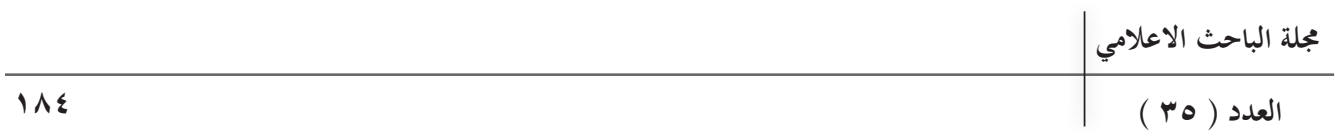




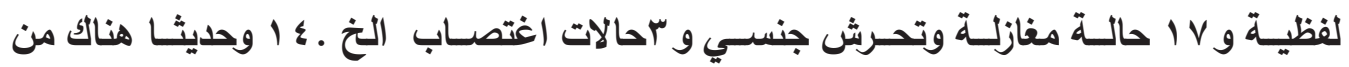

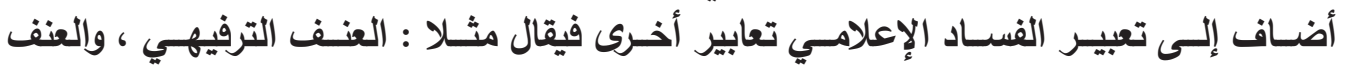

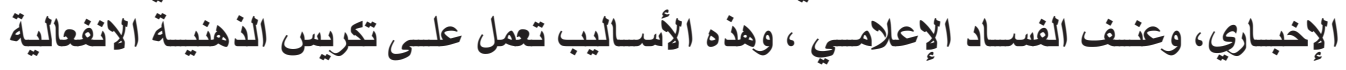

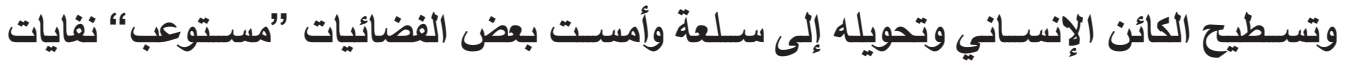

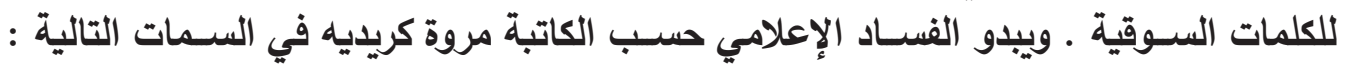

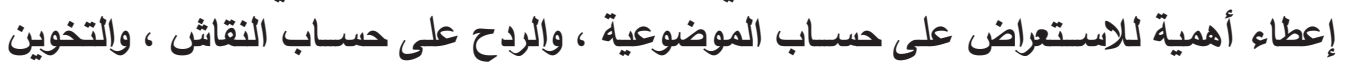

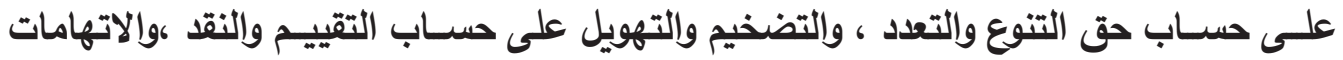

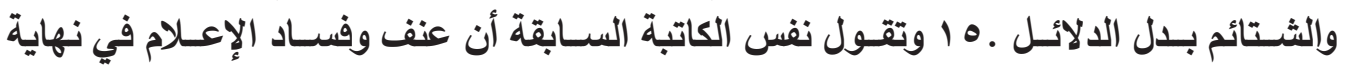

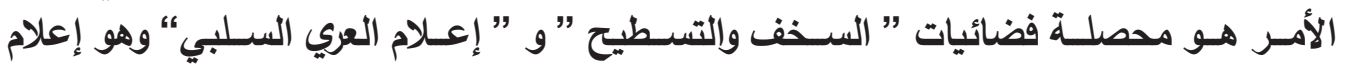

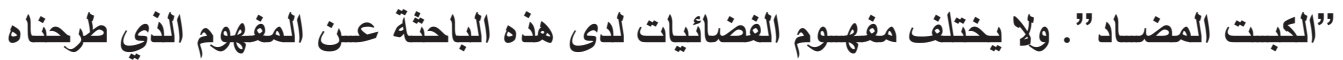

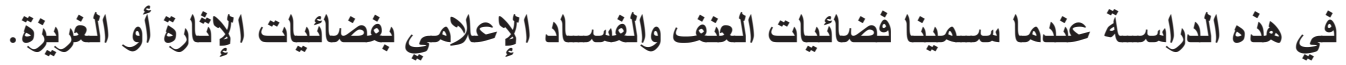

\section{ثالثا - اللغة العربية: لمحة تاريخية}

تنحدر اللفة العربية 7 الالحالية من اللغة السامية المتجذرة في التاريخ الإنساني وتمتـ

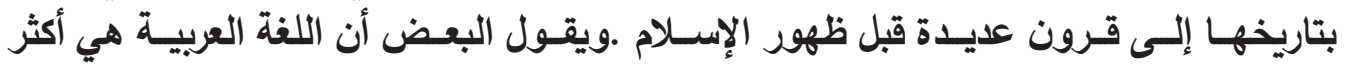

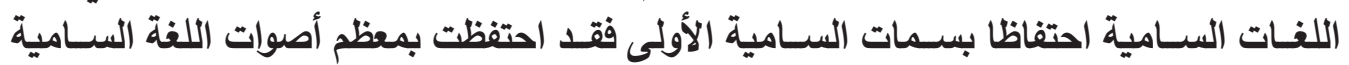

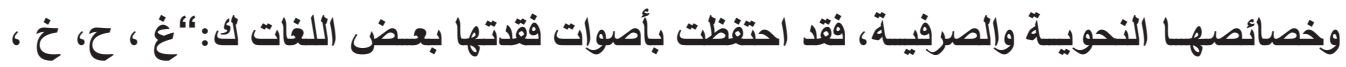

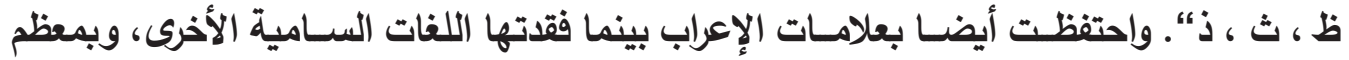

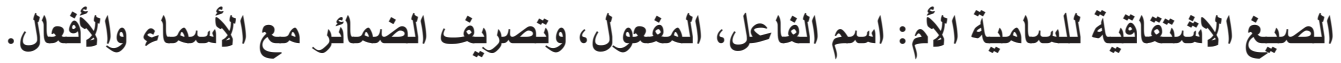

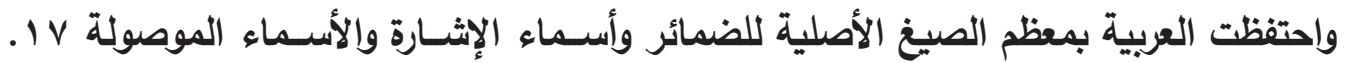

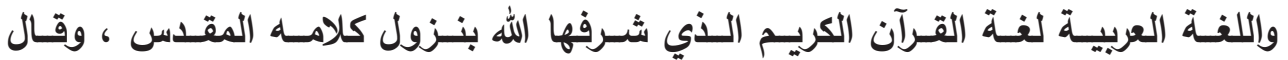

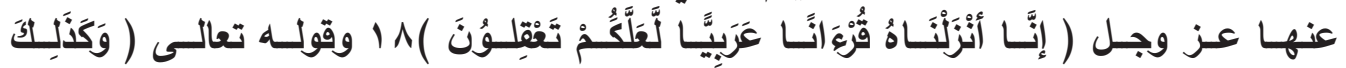

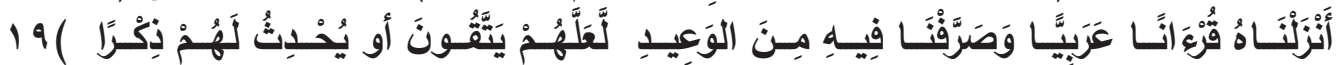

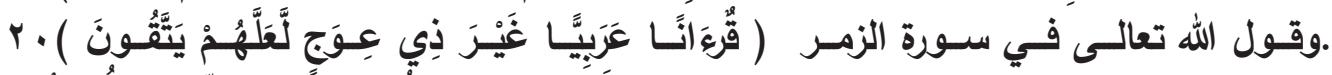

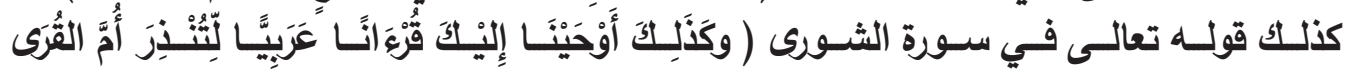

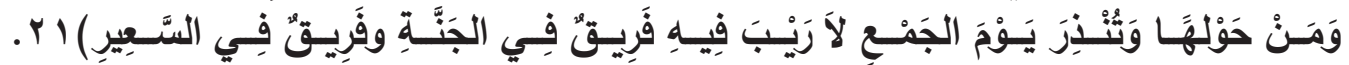

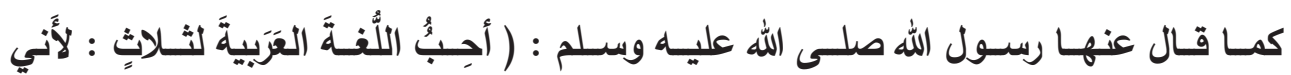

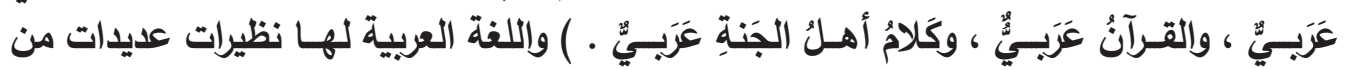

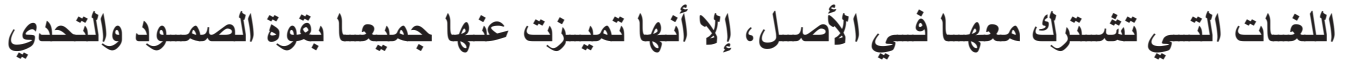


والمحافظـة علـى الروابـط التـي تصلهـا باللفة الأصـلـ ويرجع ذلك إلـى عدة عوامـل تاريخية

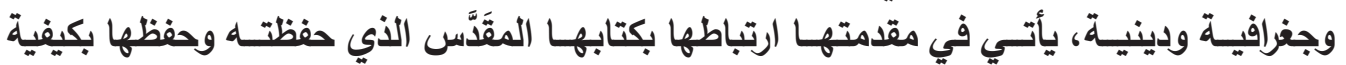

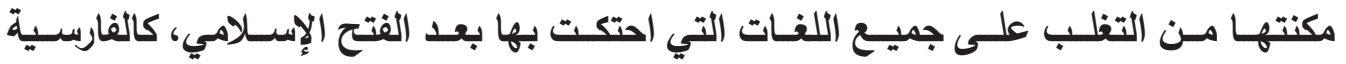

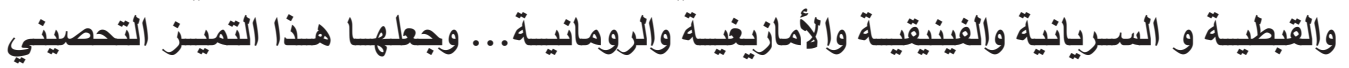

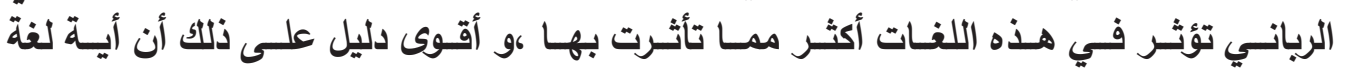

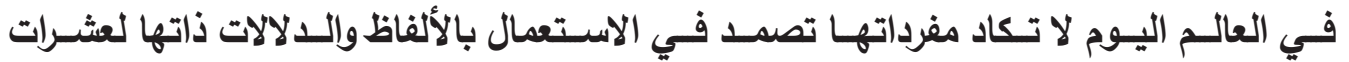

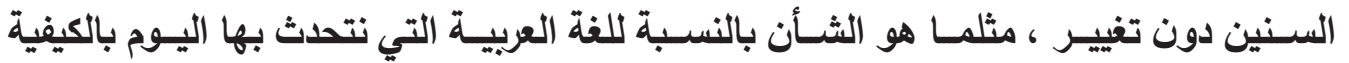

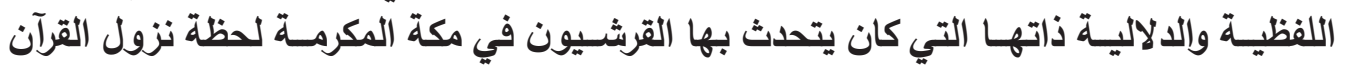

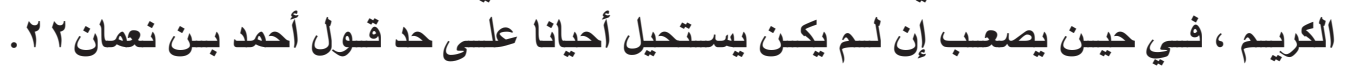

أن نقرأ نصا لايكارت أو شكسـبير أو موليير أو نص أدبي إنجليزي أو فرنسـي أو إسـباني

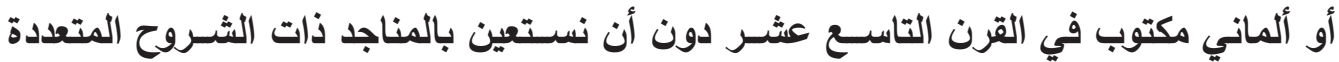

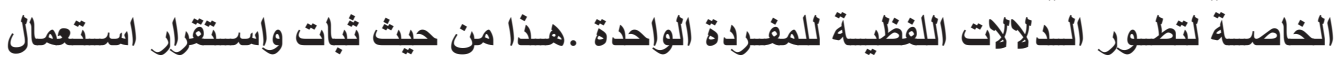

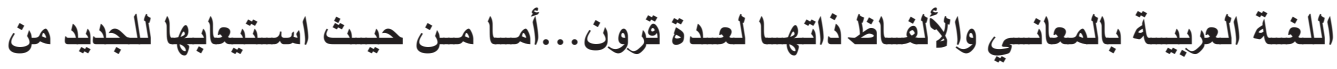

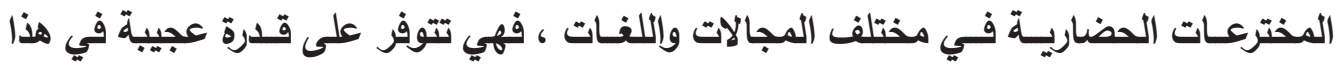

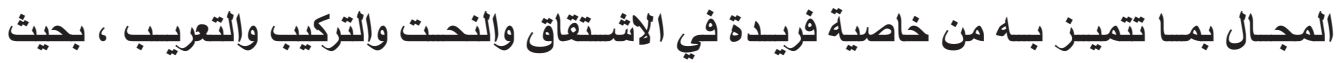

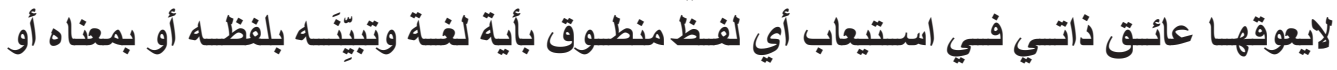

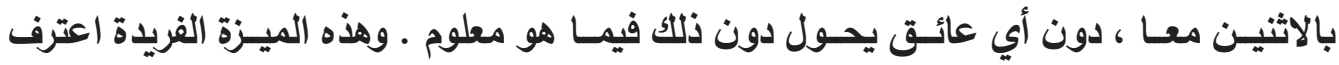

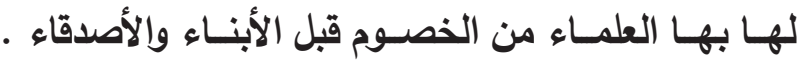

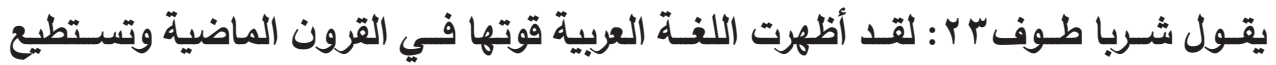

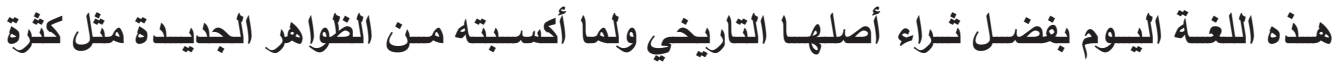

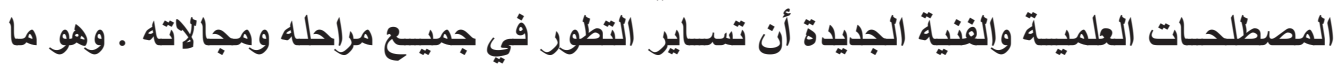

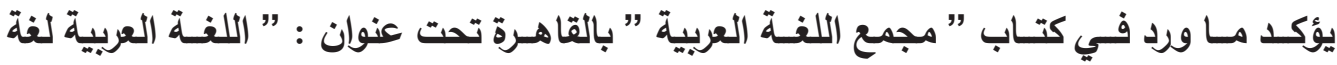

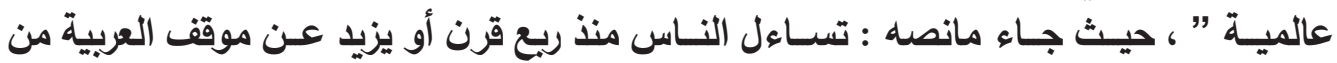

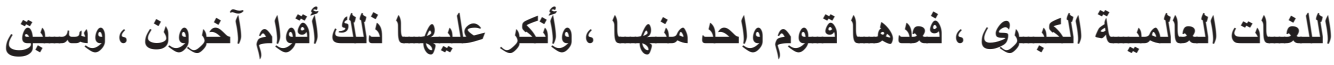

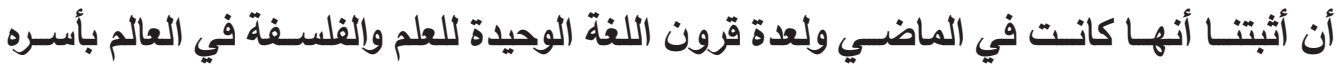

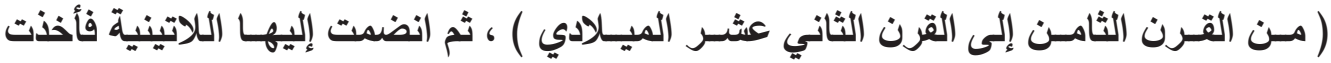

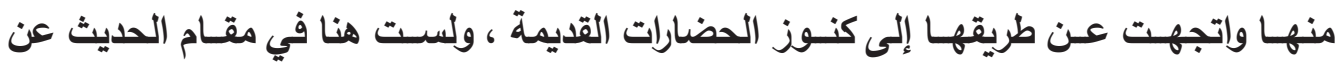

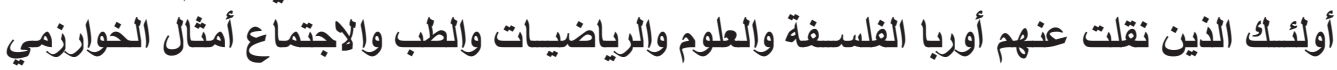




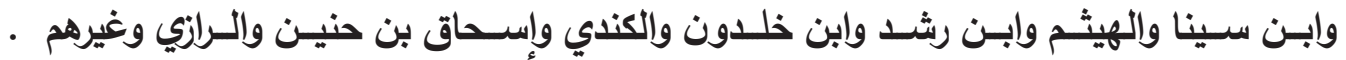

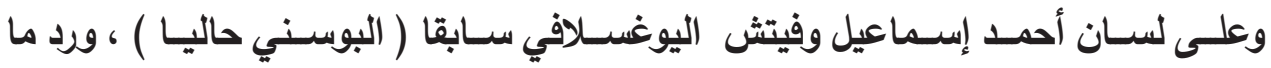

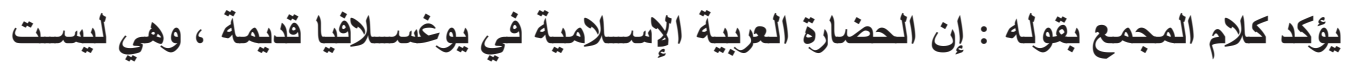

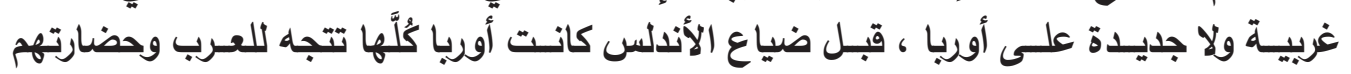

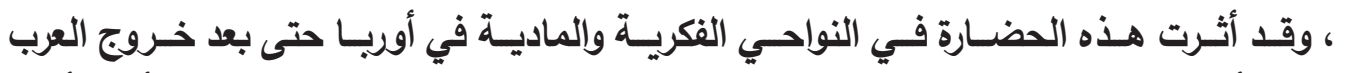

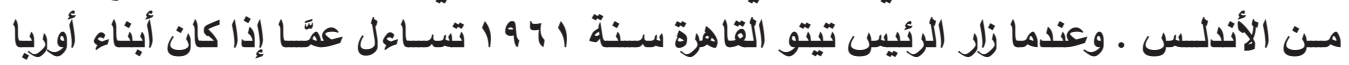

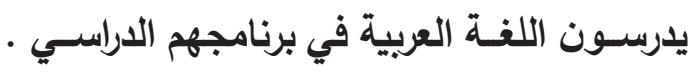

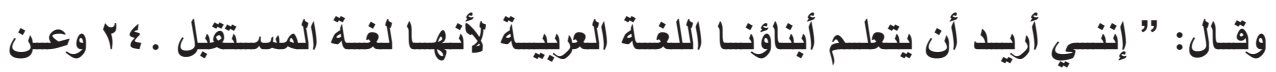

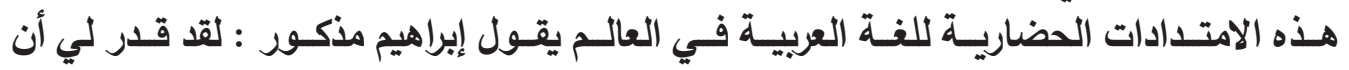

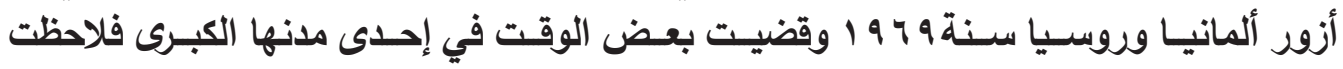

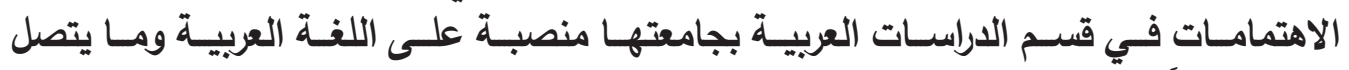

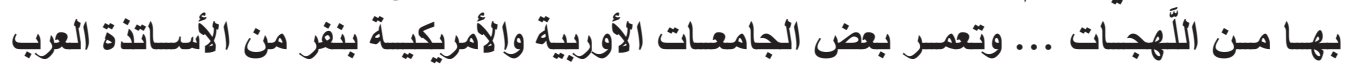

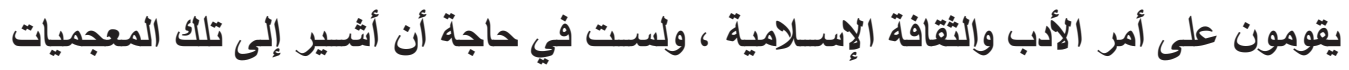

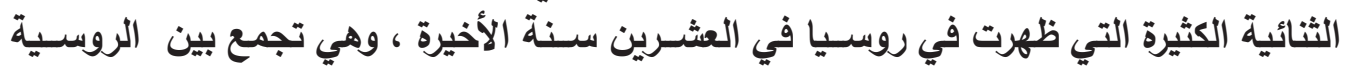

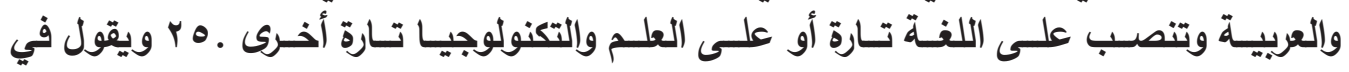

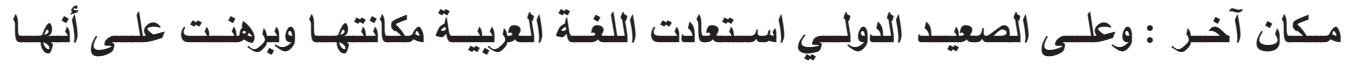

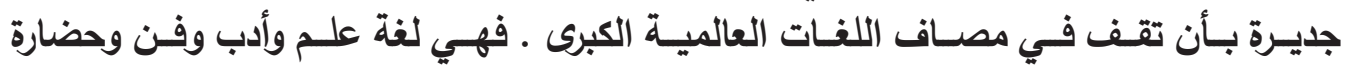

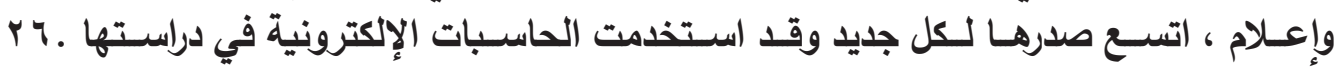
رابعا - اللغة العربية الراهنة : الخلل في ماهو واقع وليس في ما ينبغي أن يكون

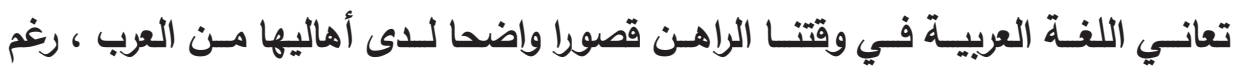

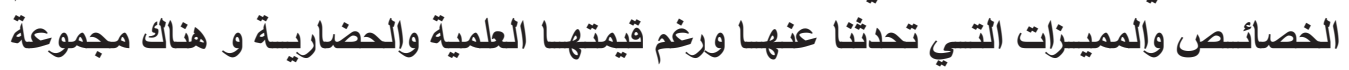

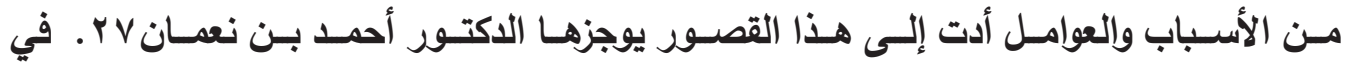

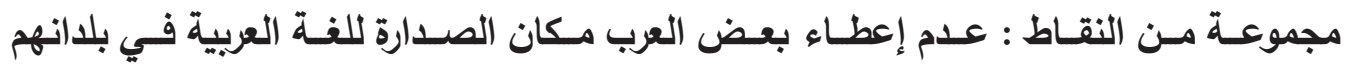

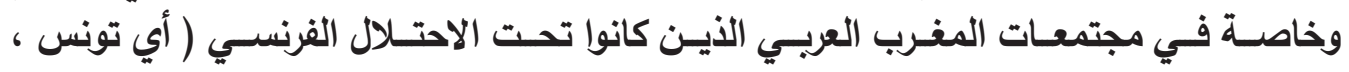

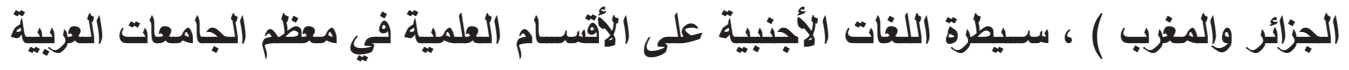

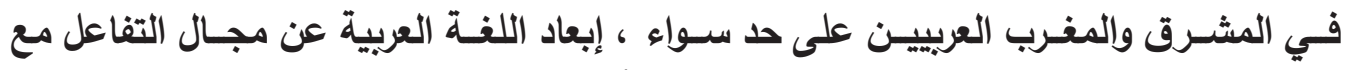

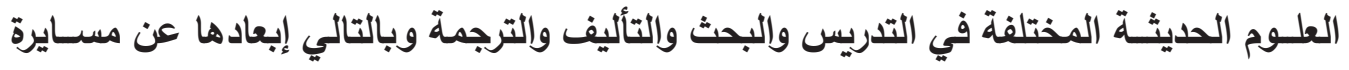

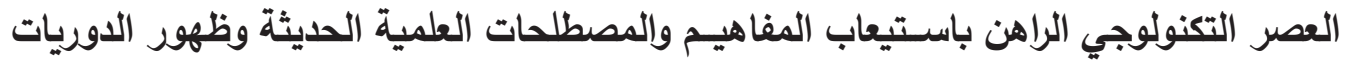




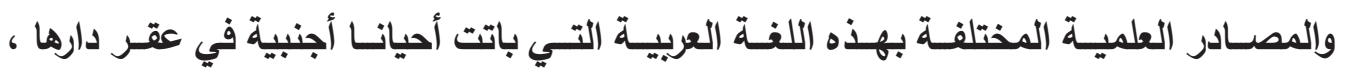

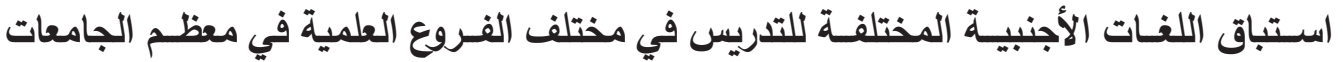

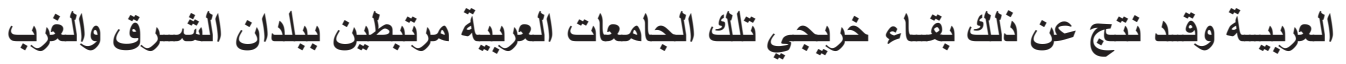

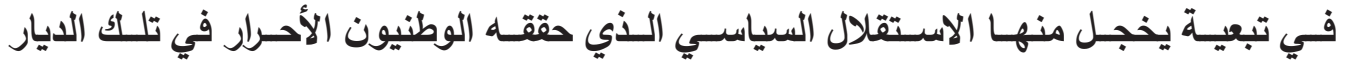

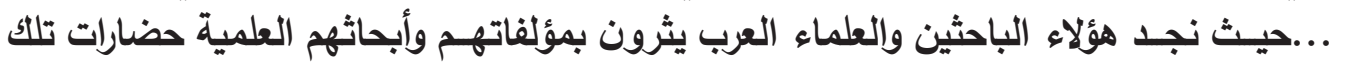

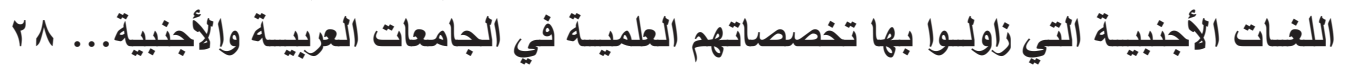

وبمعزل عن المسـاهمة في عملية الإبداع العلمي العربي الأصيل ، على غرار ما تفعله

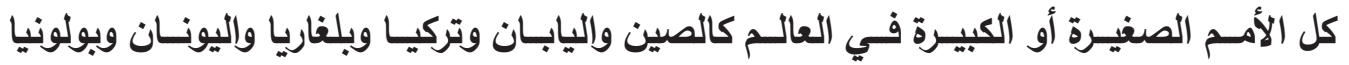

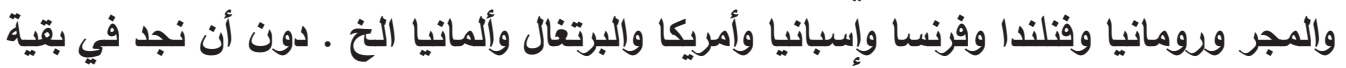

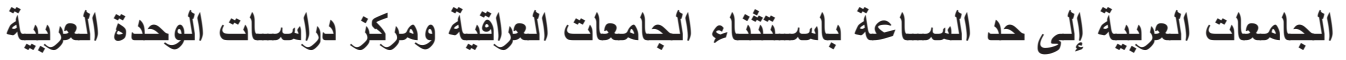

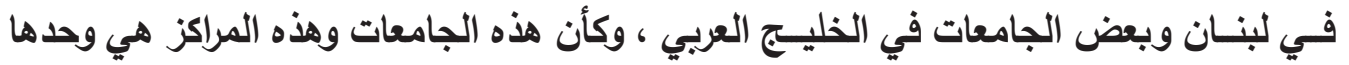

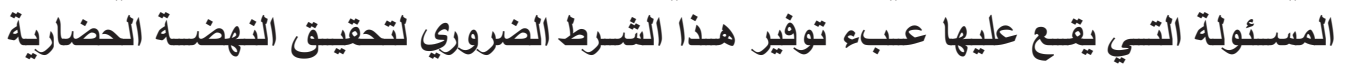

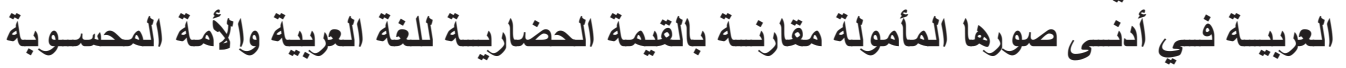

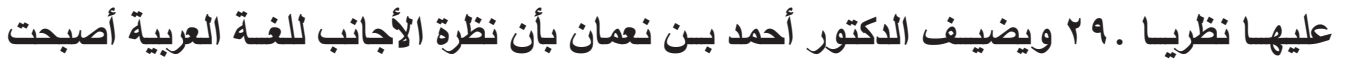

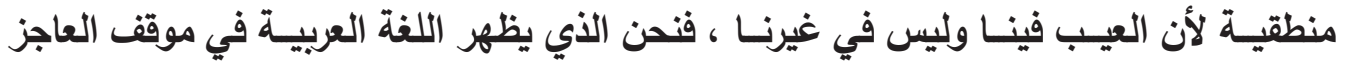

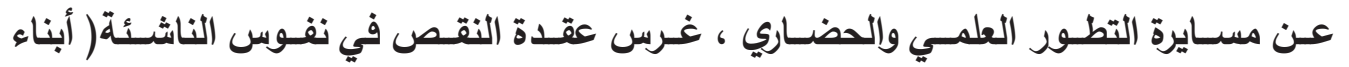

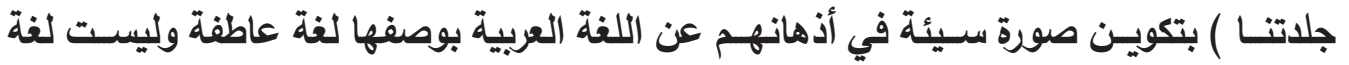

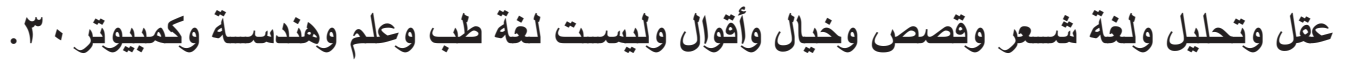

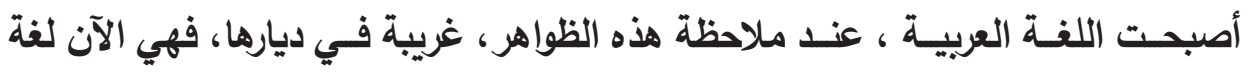

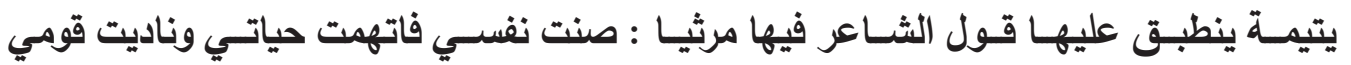

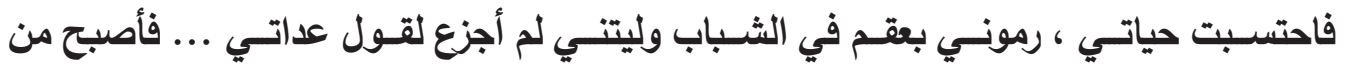

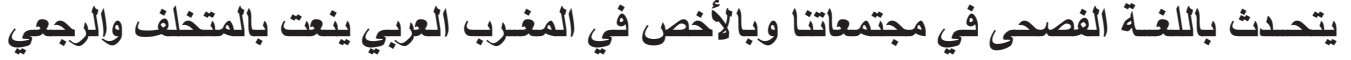

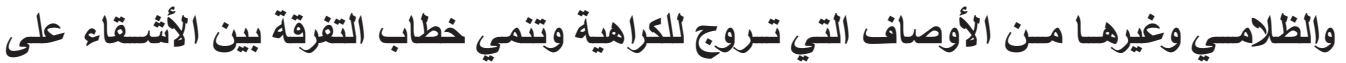

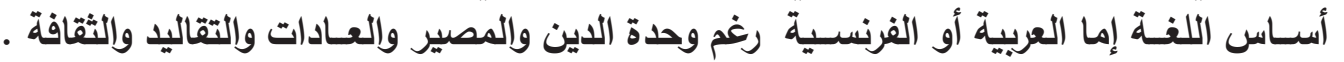

خامسا - اللغة العربية في الفضائيات:التلوث اللغوي و سيادة العامية

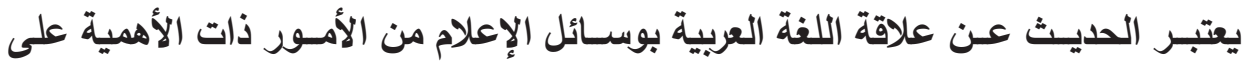

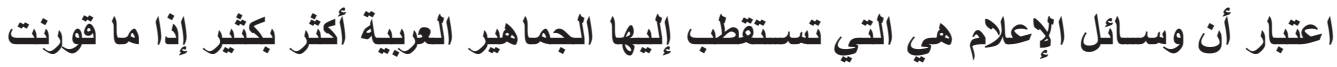

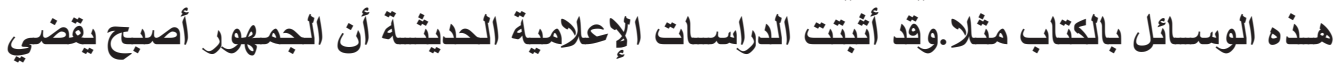

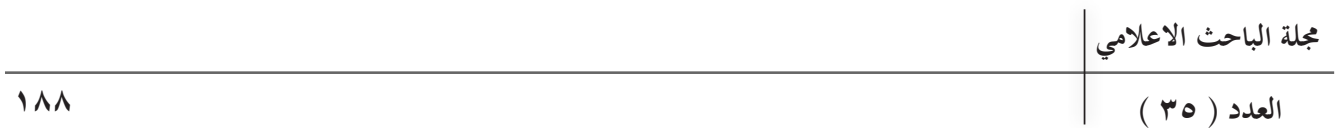


في أيامنا هذه وقتا معتبرا أمام شاشات التلفاز، قدرته إحدى الاراسات ب:،“ست ساعات يوميا“،

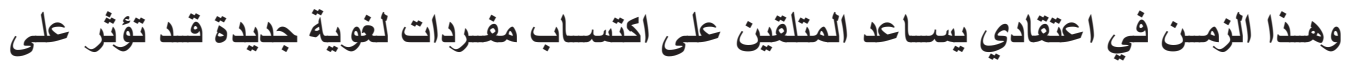
البناء اللغوي السـليم الذي يكون قد اكتــــه الفرد من قبل كعضو وهو على مقاعد الدراســة .

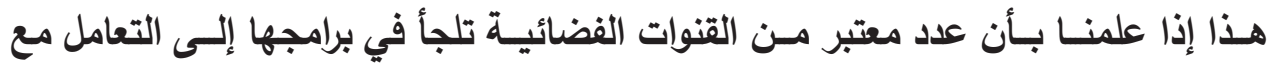

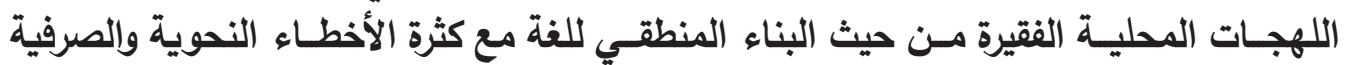

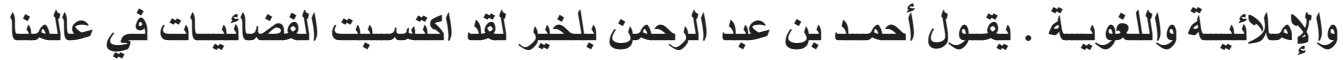

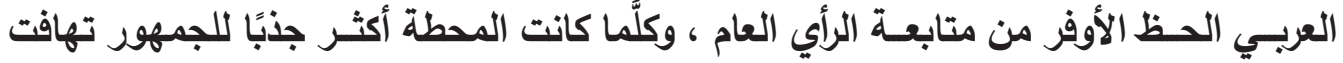

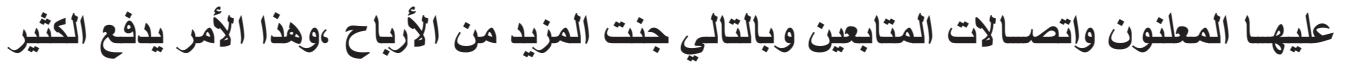

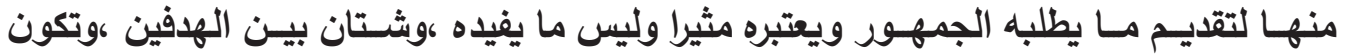

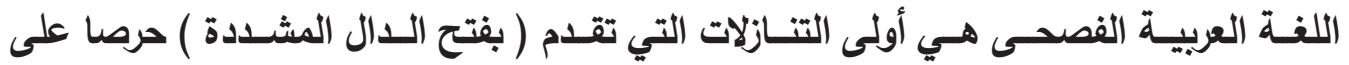

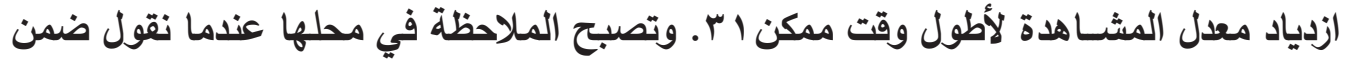

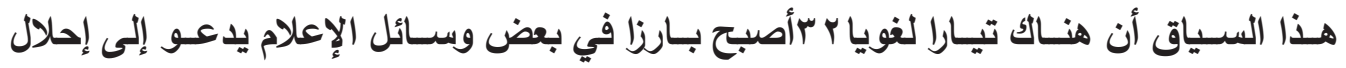

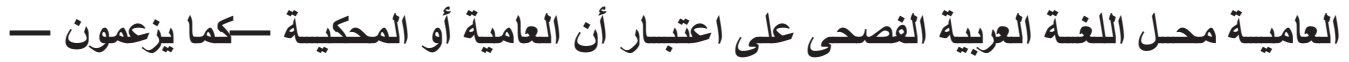

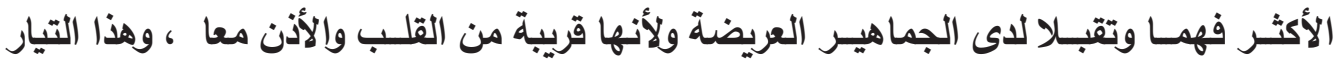

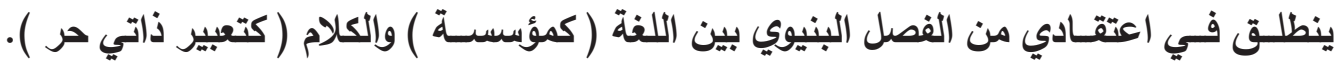

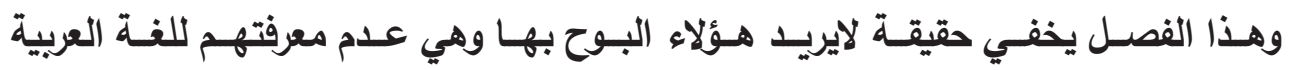

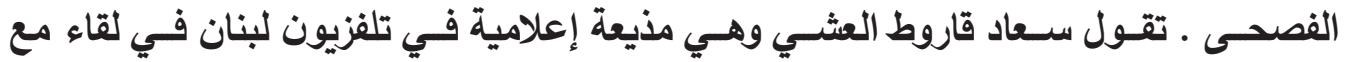

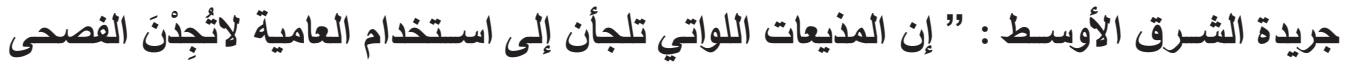

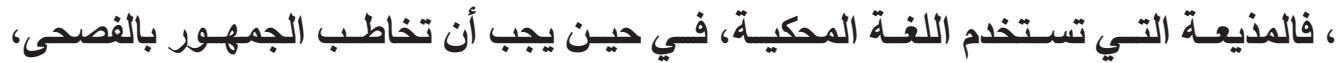

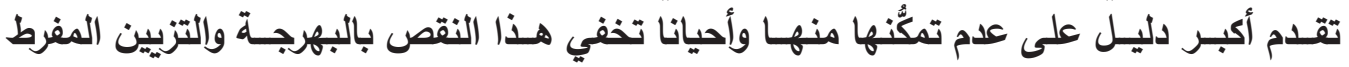

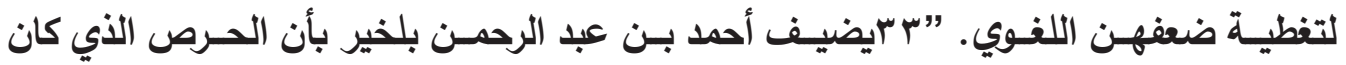

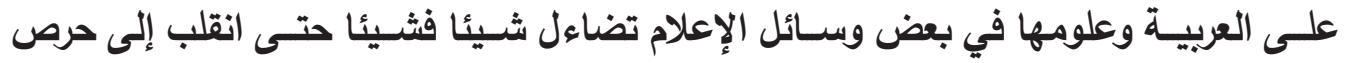

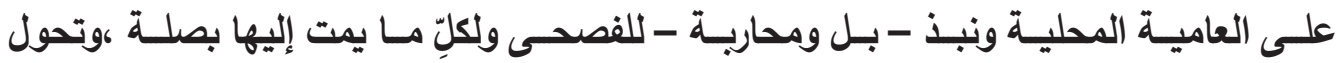

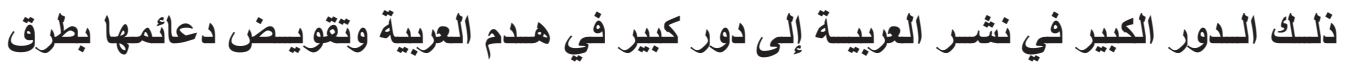

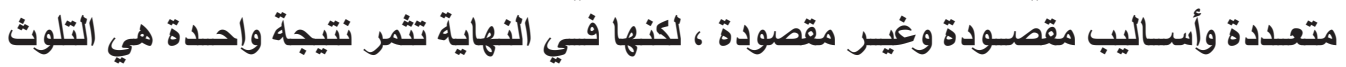

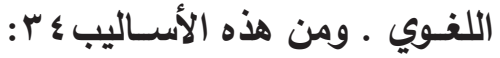

1 ـ غلبة استخدام اللهجات العامية بين الفضائيات العربية والتنافس المحموم لحيازة قصب السبق بانتثـار عامية هذه الفضائية أو تلك بين عدد أكبر من المشـاهدين حتى تنوعت وتعددات 
لهجـات الفضائيـات بعدد الدول العربيـة فخلنا فيما يسـى : " الازدواجية اللغوية "هـ ب.

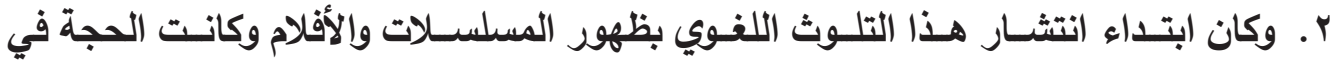

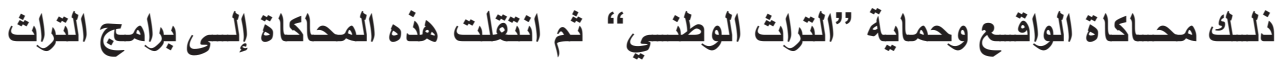

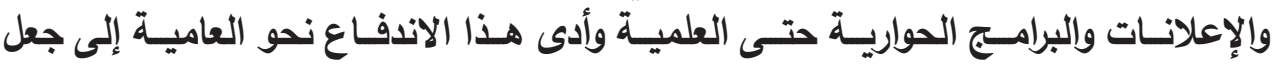

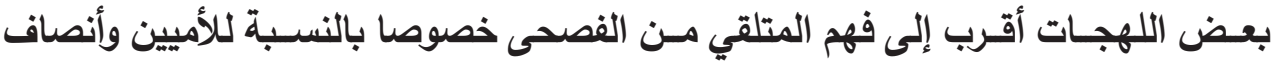

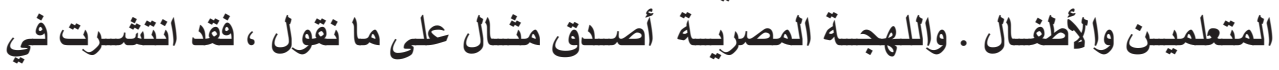

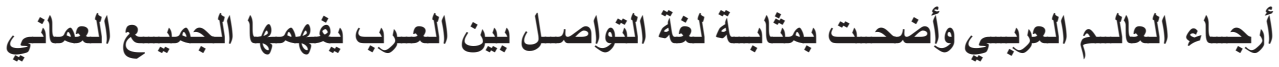

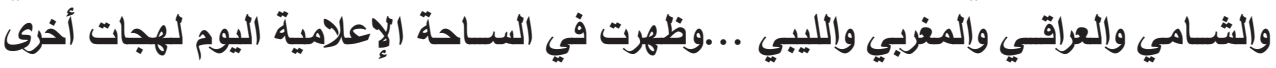

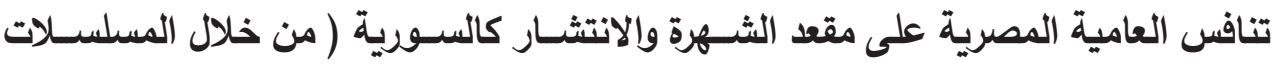
التركيـة المدبلجة خاصـة ) والخليجية وغيرهما.

r. كثرة اسـتخدام اللفـة الأجنبية فـي الفضائيات العربية ، فمســى القنـاة (Canal) أجنبي

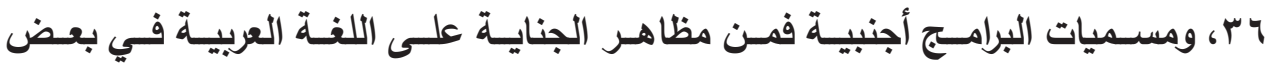

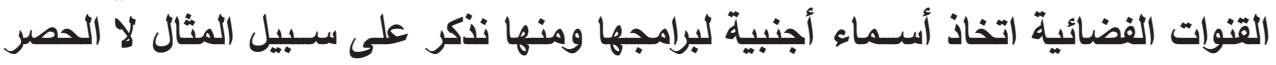

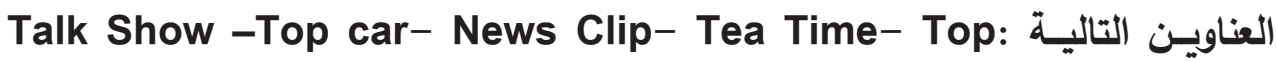
ten - Melody

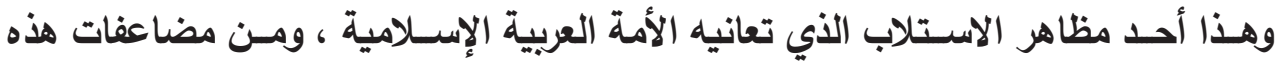

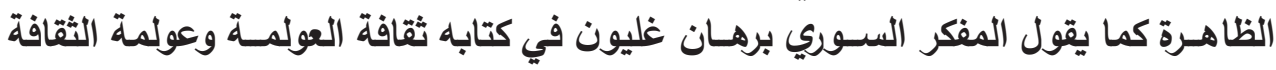

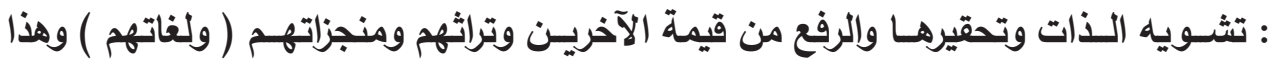

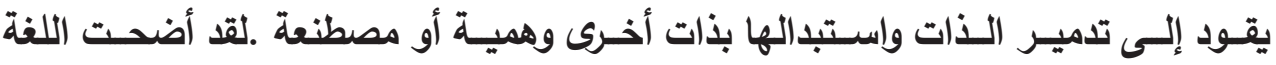

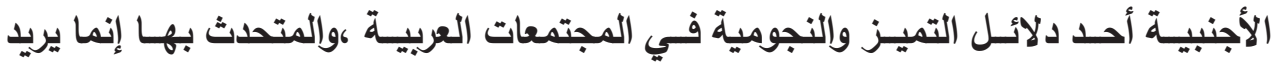

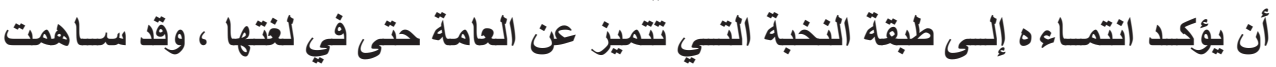

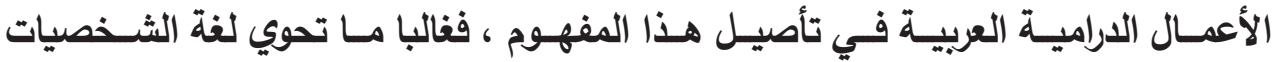

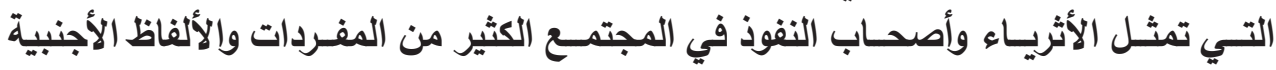

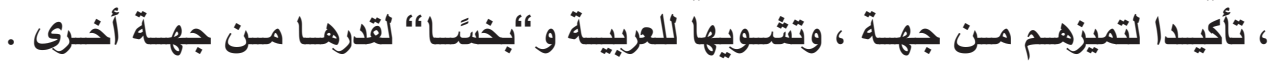

ـ. تعـــ بعـ الفضائيـات على إظهار الفصحى فـي الأعمال الارامية وغيرهـا على أنها لغة

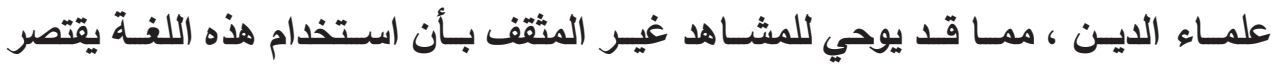

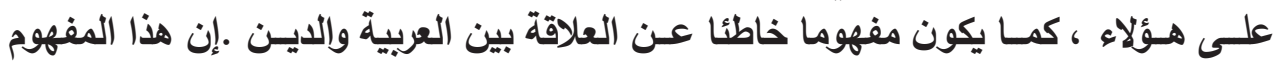

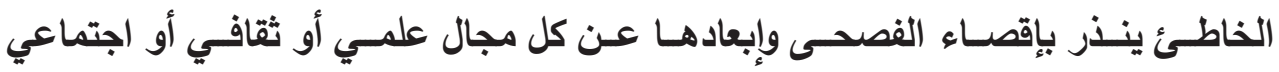

\begin{tabular}{l|c} 
& مجلة الباحث الاعلامي \\
\hline 19. & ( العدد (T)
\end{tabular} 


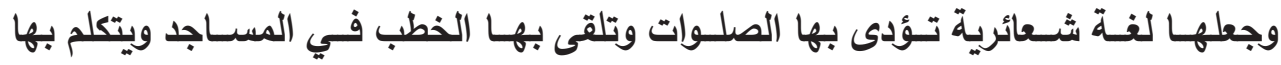

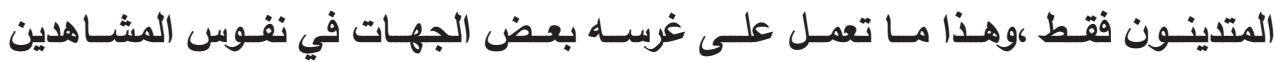

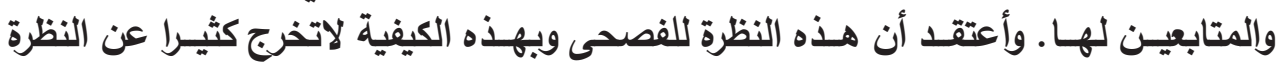

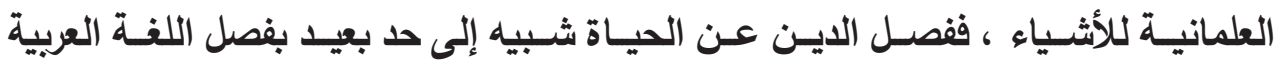

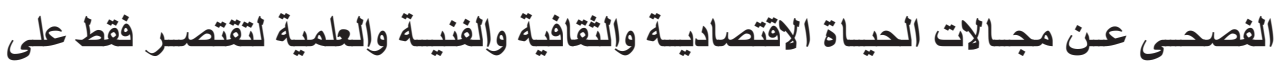
قضايـا العبادات والوعض والإرشــاد .

يتحـدث عمـر الزيـن V ف في هذا الإطار عن مؤامرة خطيرة تعـاك اليوم ضد اللغة العربية

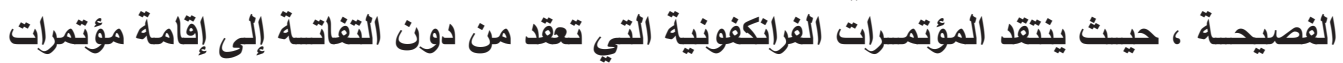

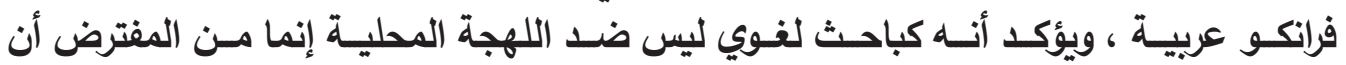

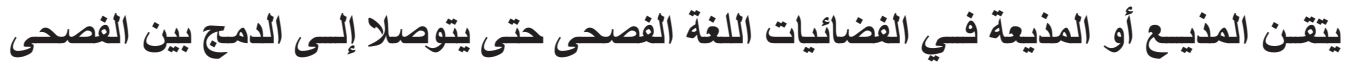

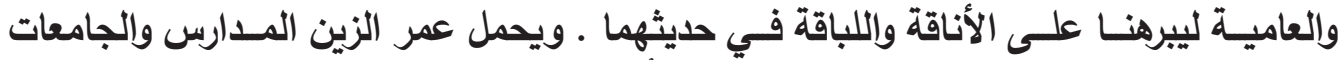

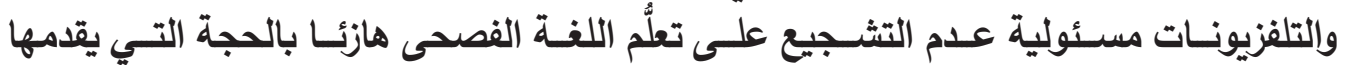

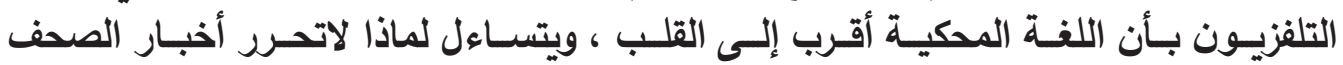

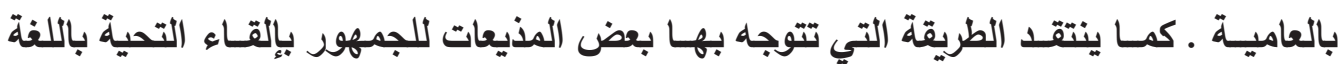

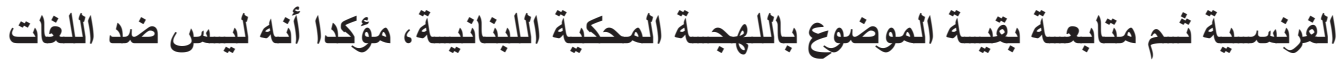

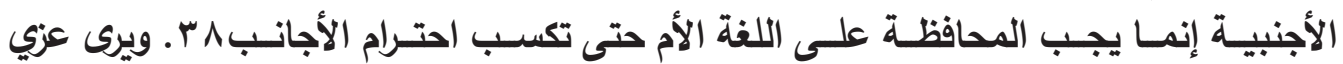

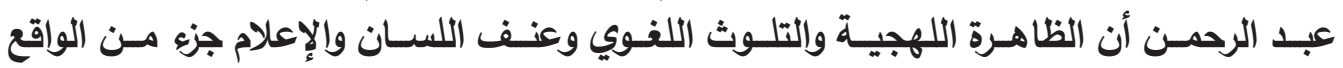

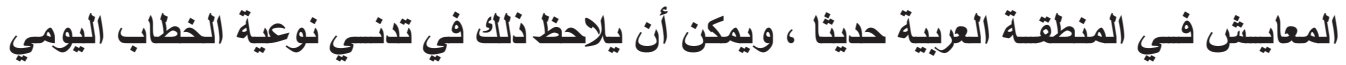

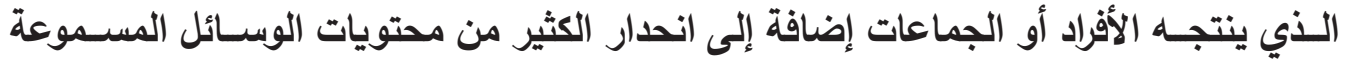

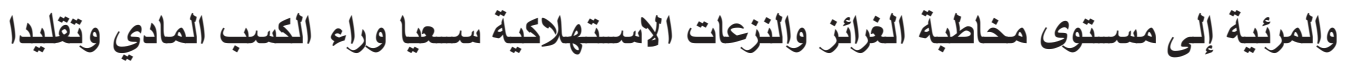

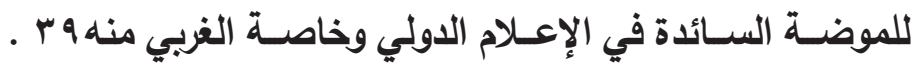

سادسـا - اللغــة العربيـة والكفــاءة القيميـة : دعـوة إلـى ربــ اللسـان بالفصحى وإعـادة الاعتبـار للقيمـة:

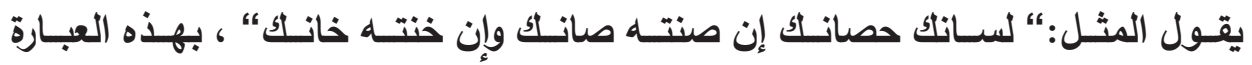

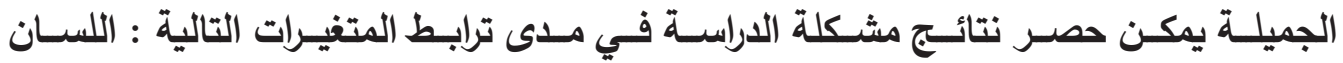

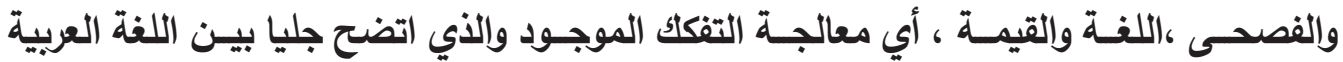

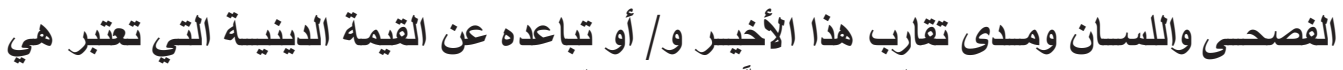

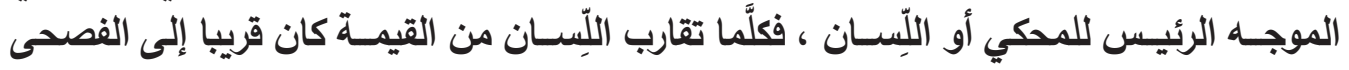




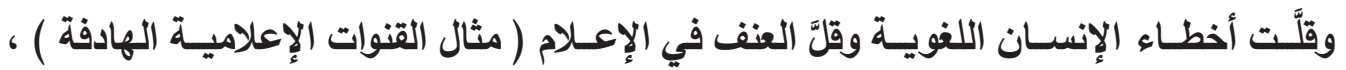

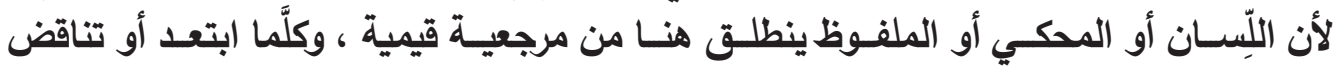

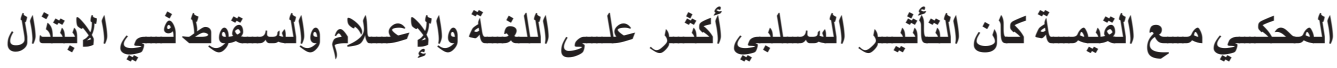

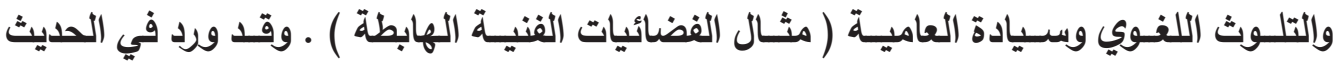

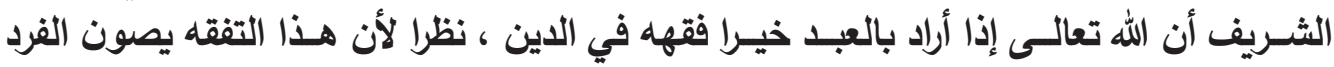

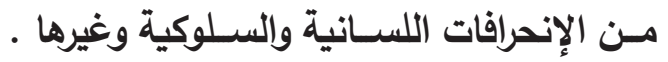

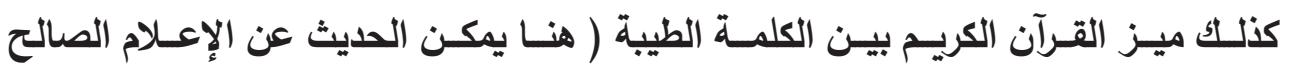

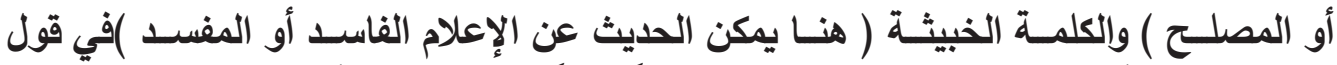

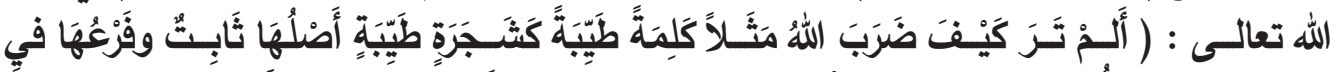

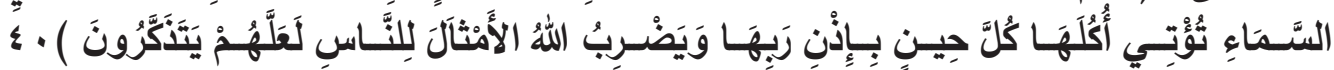

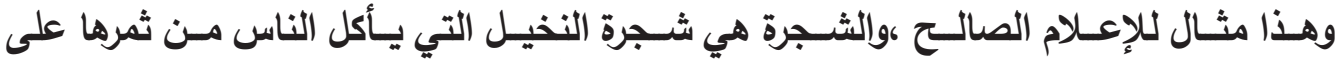

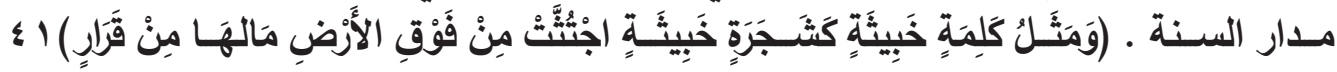

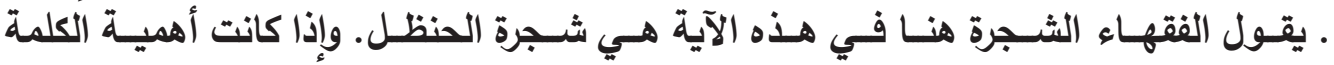

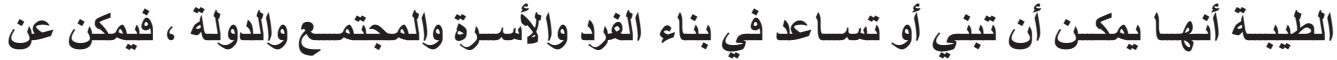

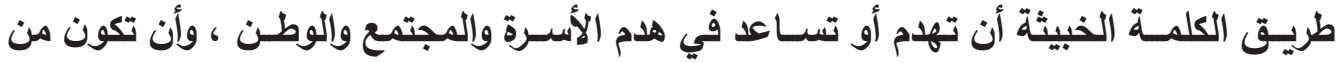

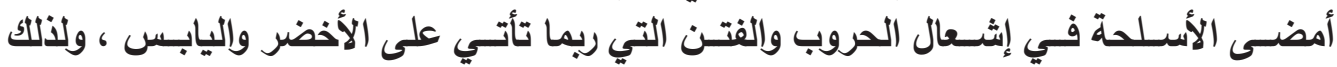

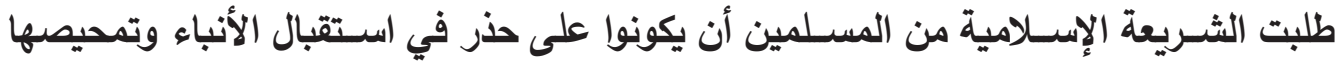

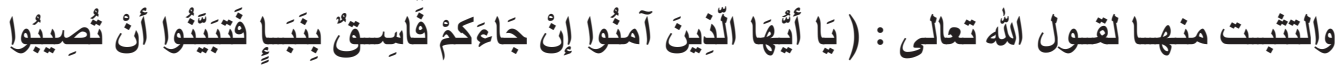

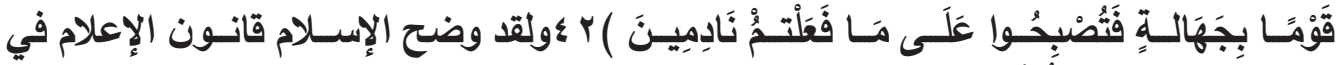

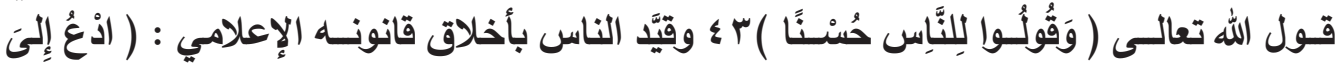

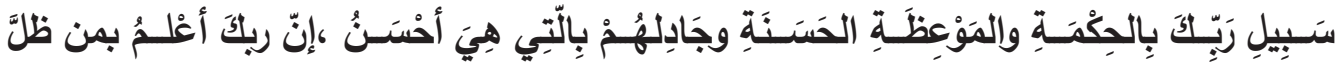

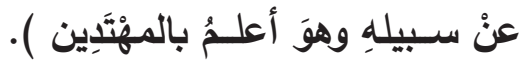

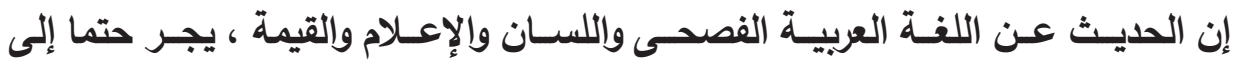

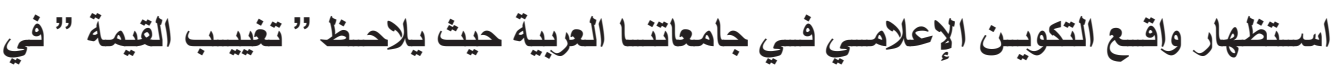

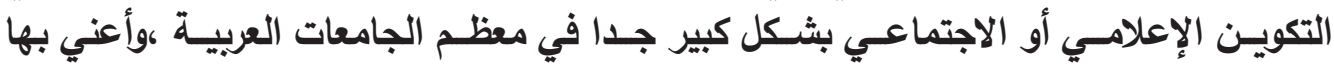

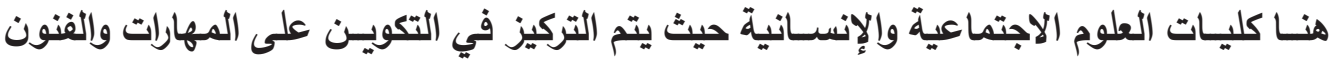

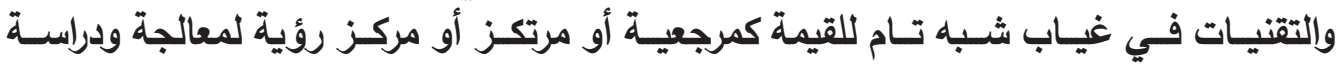

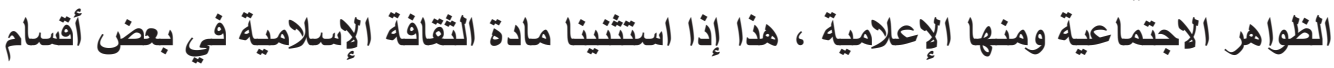




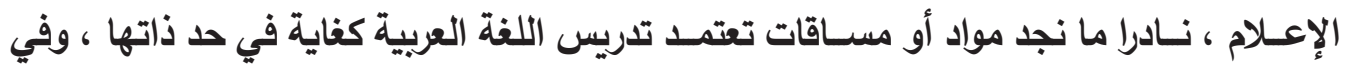

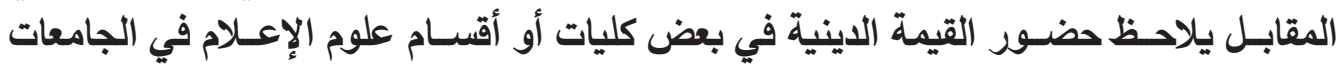

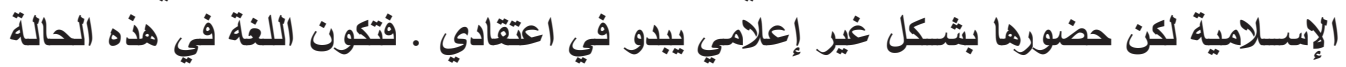

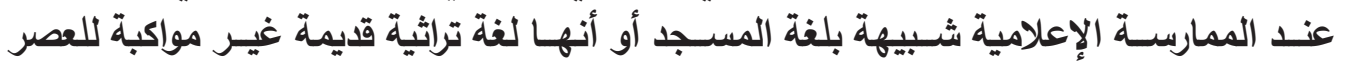

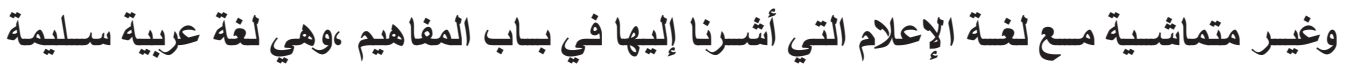

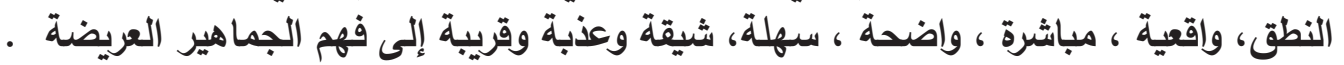

\section{الإحالات}

1 ا ـإن اللفـة العربيـة أكثر لغــات المجموعة السـامية متحدثيـن ،وإحدى أكثر اللغات انتشـارا

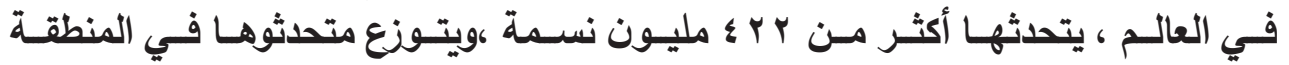

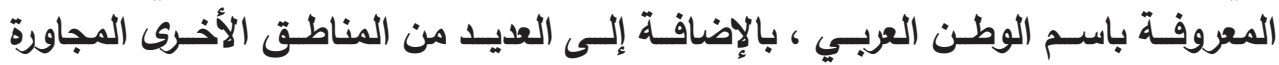

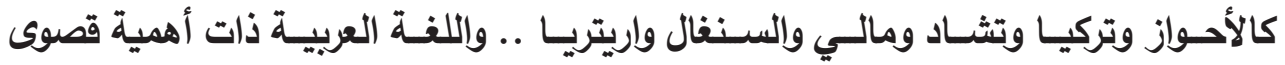

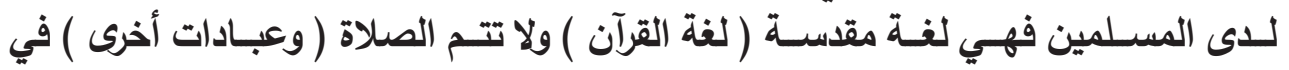

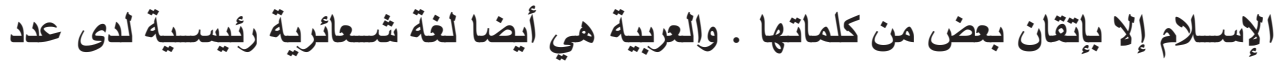

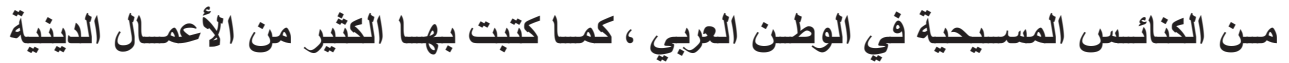

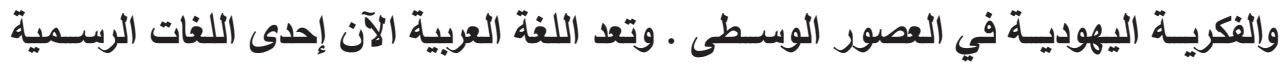
الســ فـي منظمة الأمــم المتحدة.

r · إن مـن يعـود إلـى أمهات الكتب العربية القديمة كطبقات فحول الثـعراء والثــر والبيان

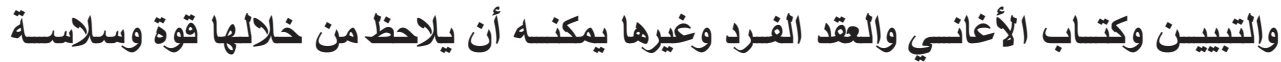

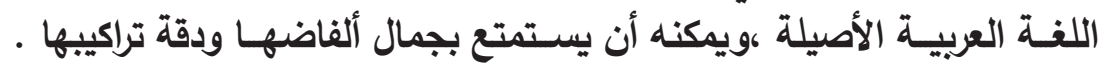

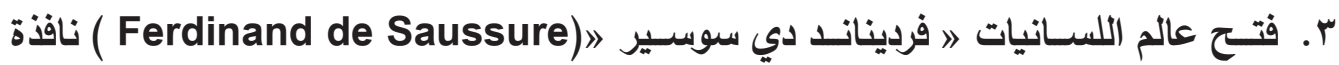
جديدة في دراسـة اللغة عندما ميز بين اللغة ( La langue ) والكلام (

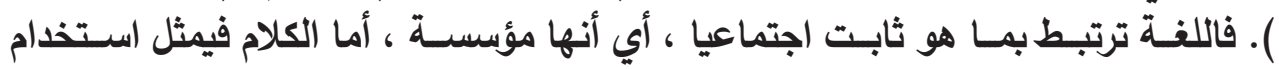

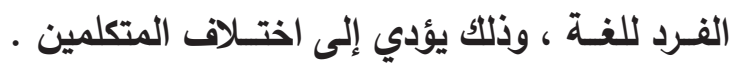

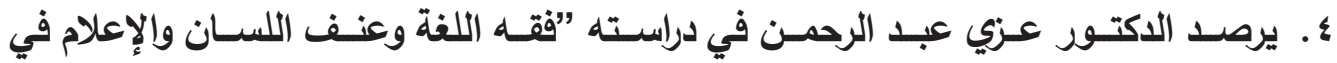

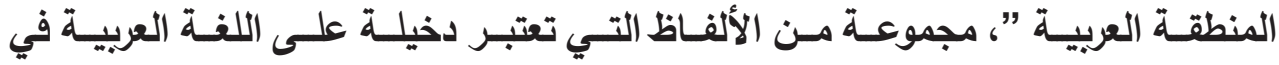

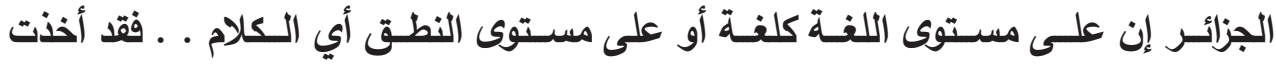

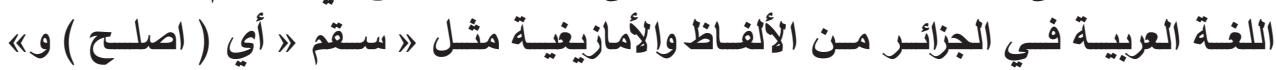




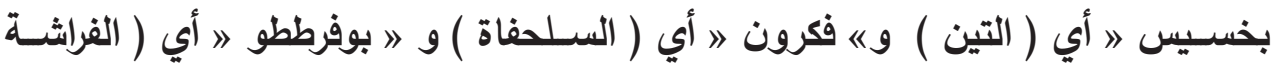

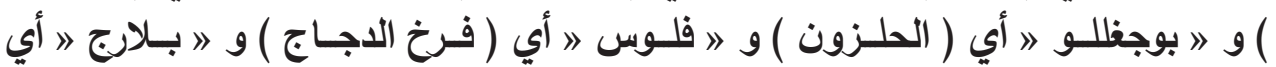

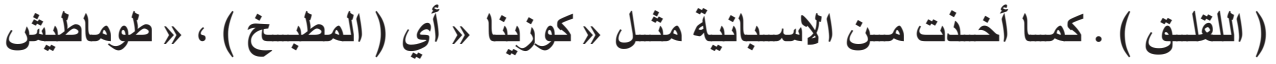

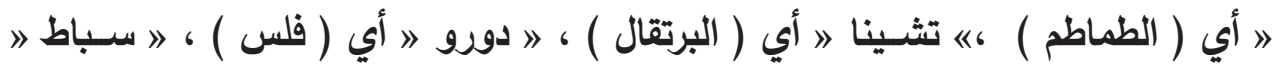

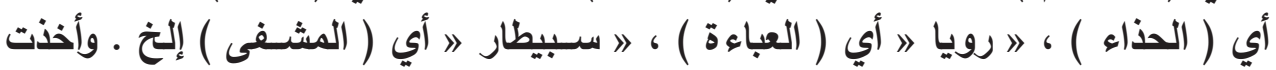

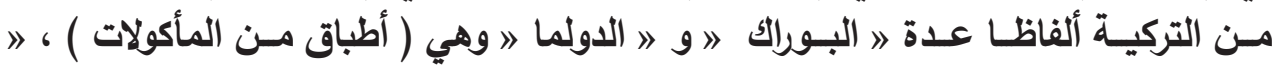

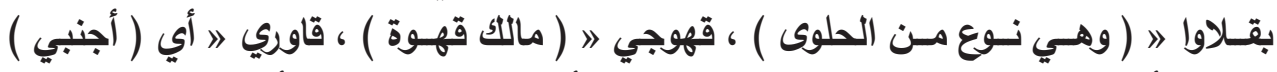

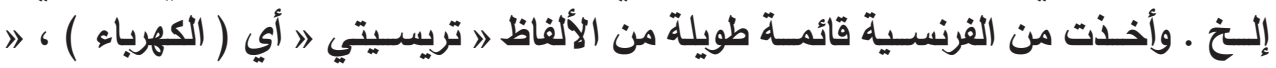

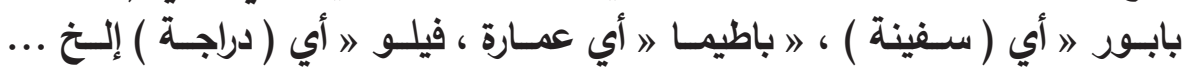

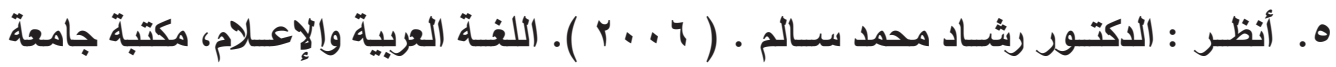

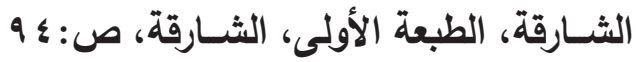

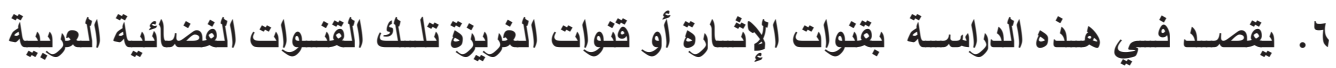

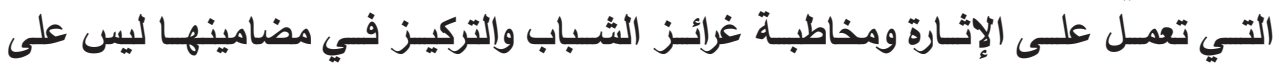

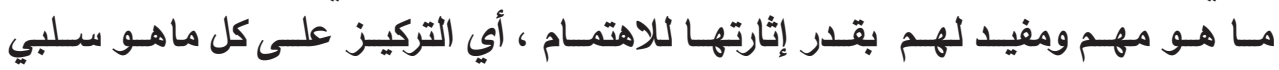

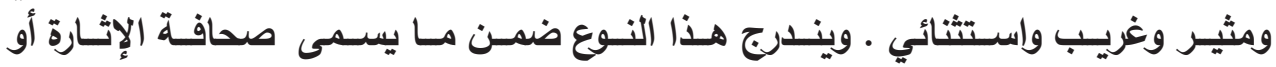

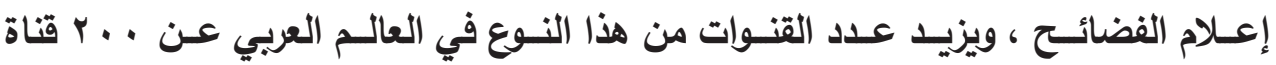

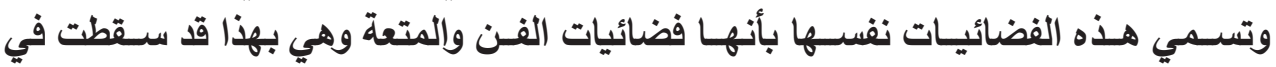

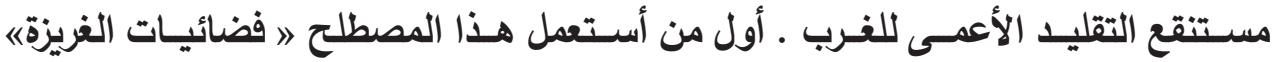

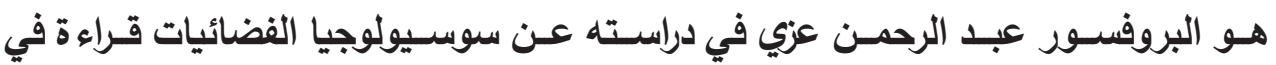

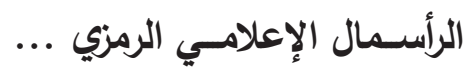

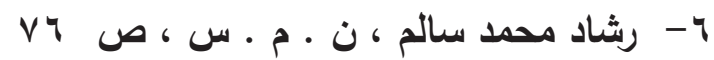

V- يمكـن الإثـــارة هنا إلى الأسـلوب الهزيـلـل واللغة العربية المبتذلة والخلــ المتعمد بين اللغة

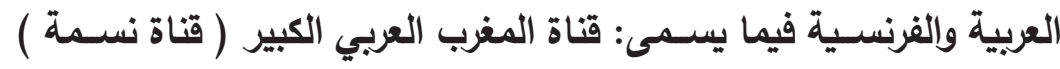
^ - المعجم الوسيط. ( $19 \vee r$ ) ) ـ مجمع اللغة العربية بالقاهرة الطبعة الثانية. 9- رشاد محمد سالم ، ص 10 • 1 - أنسس تـاس مساري الكرملي ، نشـوء اللغة العربيـة ونموها واكتهالهـا ، المطبعة العصرية 


\section{، القاهـرة ، مصـر ، 1 9 | ، ص זr}

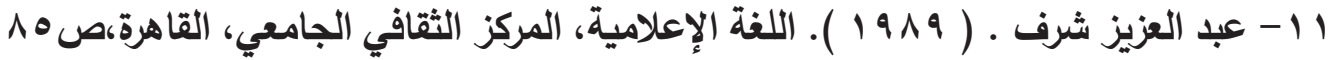

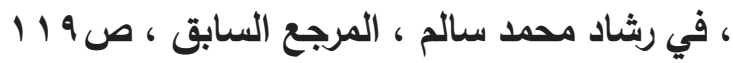

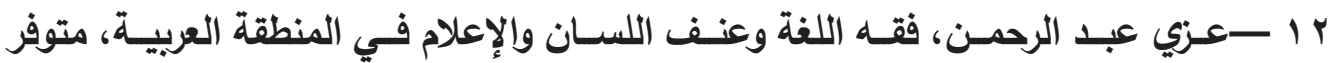
على الرابـط التالـي: با ا - فعــف الإعـلام ظاهـرة جزئيـة إذ وبالطبع ليسس كل ماهو إعلامي ينتــي إلى هذا العنف

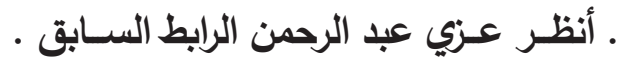

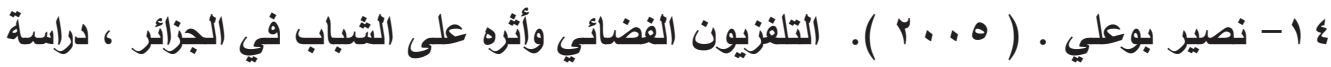

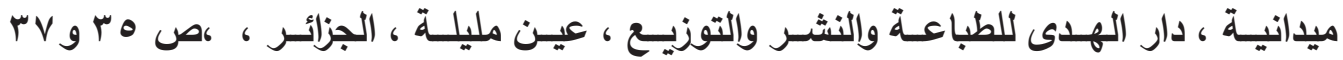

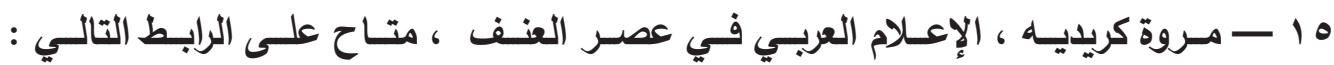
. r. $11 / \cdot r / r \wedge$ http://www.diwanalarab.com/spip.php?article I r०१ r

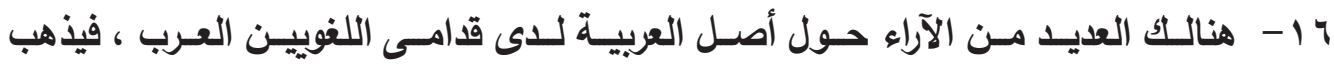

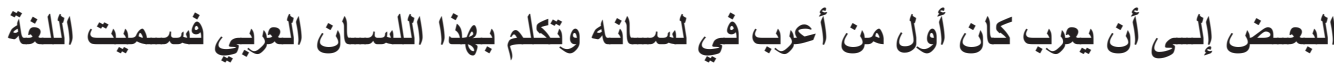

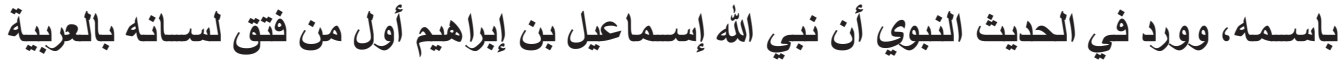

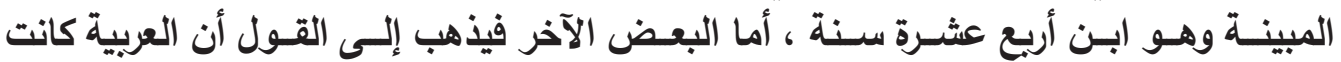

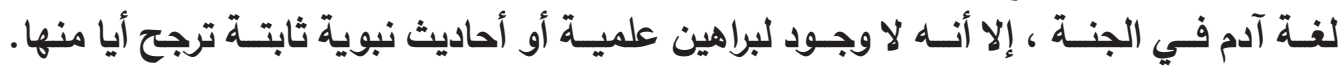
V ا - عن تاريخ الأبجدية العربية متاح على الموقع التالي : وكبيا يا الموسوعة الحرة على الانترنت .

$$
\begin{aligned}
& \text { 11- يوسف، r. } \\
& 9 \\
& \text {. . الزمر ، Y . } \\
& \text { ا Y- الثورى ، V. }
\end{aligned}
$$

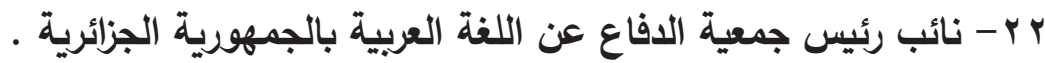
r r - وهو من أكبر المستشرقين الروس

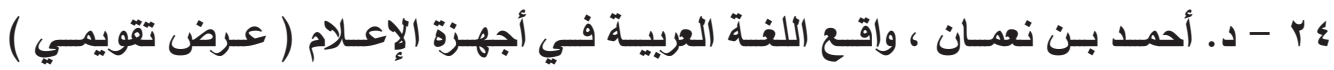

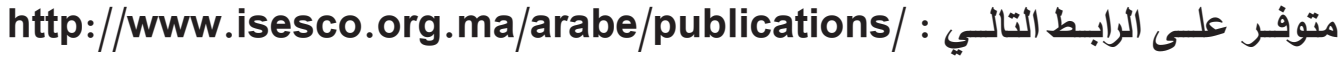

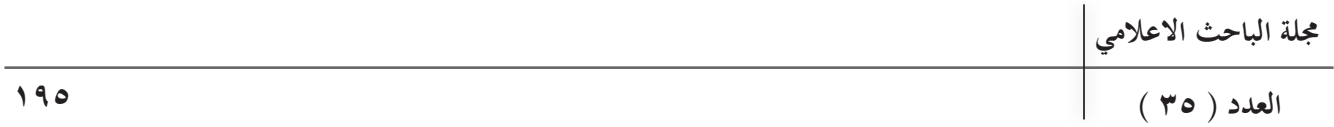


$(r \cdot 11 / \cdot r / \cdot q)$ php.langue_arabe/pr

ه r- - د. أحمد بن نعمان ، نفس الرابط السابق .

צ ץ - د. أحمد بن نعمان ، نفس الرابط السابق .

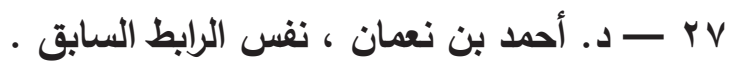

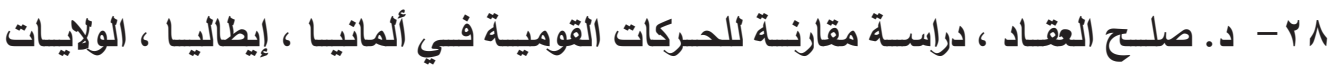

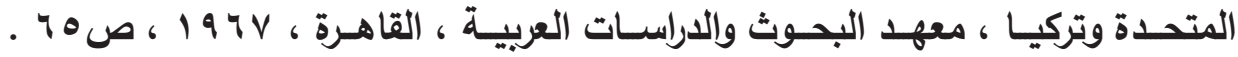

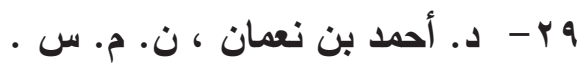

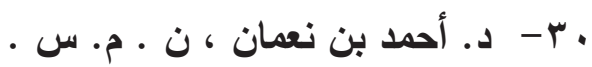

اس د. أحمــ بـن عبــ الرحمـن بلخيـر : الفضائيـات العربية والتـــوث اللغوي وسـيادة العامية

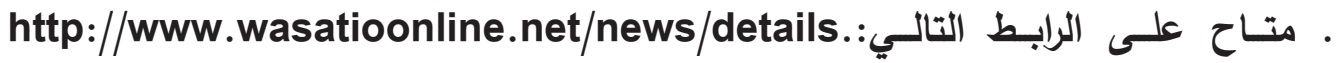

$$
(r \cdot 11 / \cdot \varepsilon / \cdot \varepsilon) \quad 1 \cdot \Lambda V=\text { php?data_id }
$$

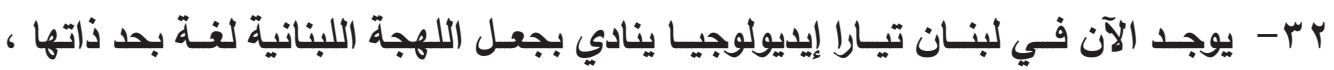

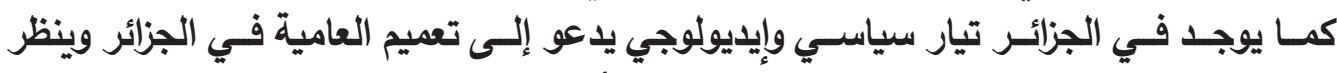

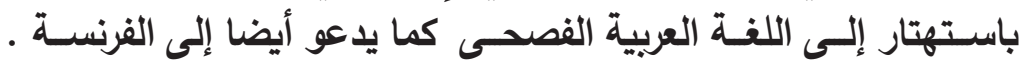

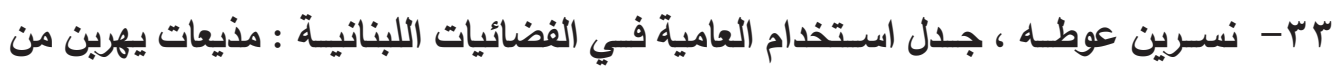

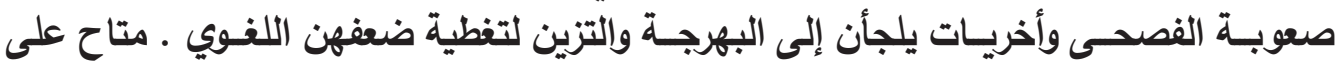

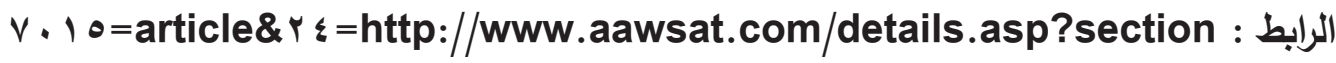

$$
(11 / \cdot \varepsilon / \cdot \varepsilon) \vee 9 r_{0}=\text { issueno\& } 4
$$

ع ب- - نسرين عوطه ، نفس الرابط السابق هـ ب- تطلق تسـية الازدواجيـة اللغوية على لغتين متثـابهتين من أصل واحسـ ، وهي ظاهرة

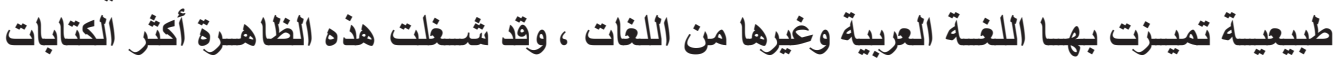

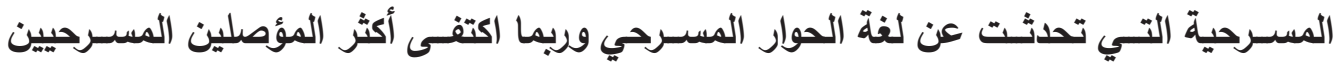

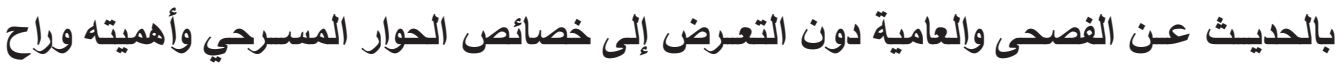

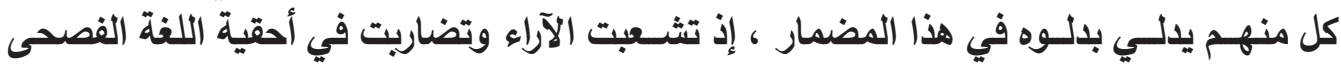

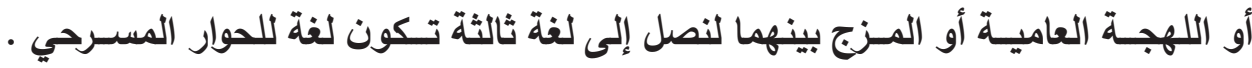

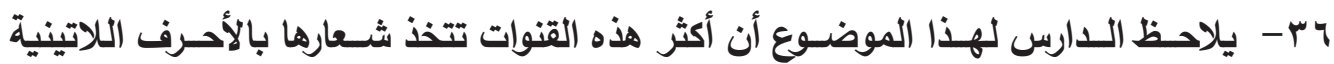


مثـلا : MTV - ANN- ART-NTV- NBN- MBC- NESMA وقـــ يقلـل بعض القراء

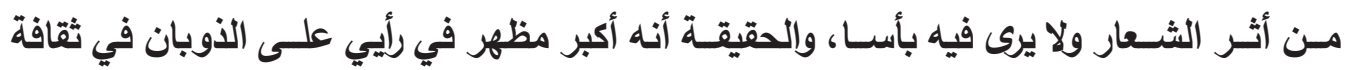

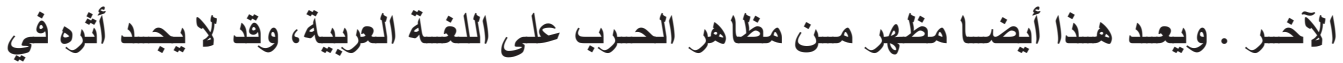

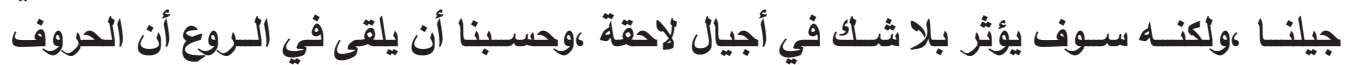

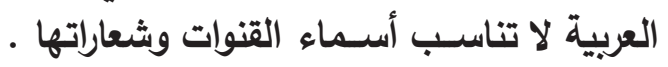

عام - خبيـر لبنانـي فـي اللغويات ومــدرب فن الإلقاء لعـد كبير من المذيعيـن والمذيعات منذ عام . 19V.

^ r- - نسرين عوطه ، نفس الرابط السابق.

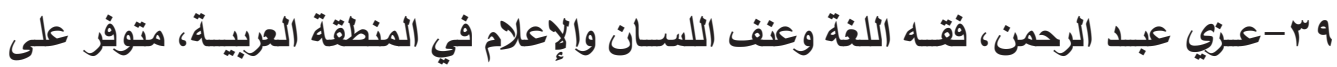
الرابط التالي:

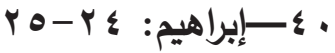

$$
\begin{aligned}
& \text { إ - إبراهيم: צr } \\
& \text { ץ צ- الحجرات: } 7 . \\
& \text { r } \\
& \text { أولا- المراجع: }
\end{aligned}
$$

1. القرآن الكريم. ( ضبطت الآيات على ما يوافق رواية حفص )

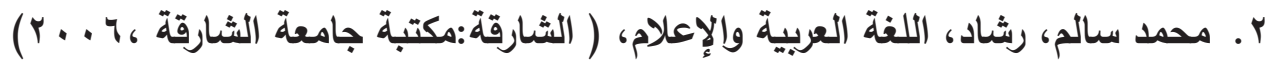

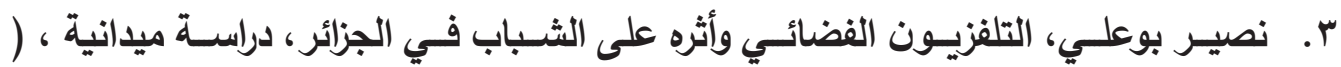

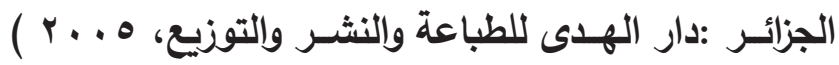

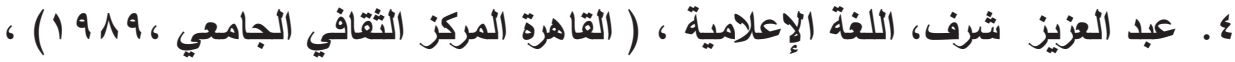
ه. عبــ التــواب رمضــان ، دراسـات وتعليقـات فـي اللفـة، ( القاهـرة : ، مكتبـة الخانجـي، (199

7 . . عبـد الرحمـن عـزي، الإعلام وتفـكك البنيـات القيمية في المنطقـة العربية: قـراءة معرفية

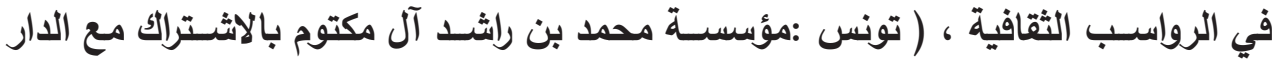

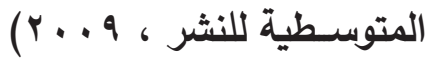

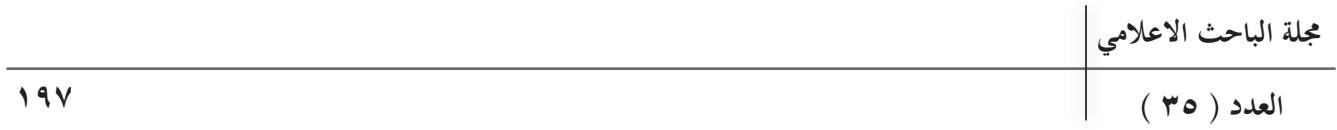


V. فخـر الايـن ، قبـاوة، المهـارات اللغوية وعروبـة اللســان، الطبعة الأولى، ( بيـروت :دار

الفكر (المعاصر، 999 (199 )

Ferdinand de Saussure, Eléments de linguistique générale, (OPU, $-\wedge$.^

$$
\text { 9. }
$$

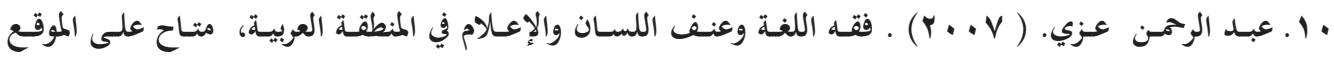

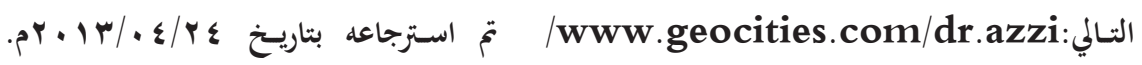

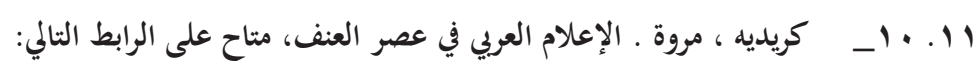

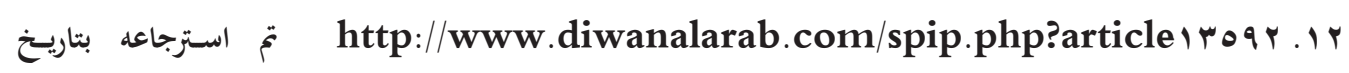

$$
\text { . } r+1 \varepsilon / \cdot r / r \Lambda
$$

ب أ. 11-1أمد ، بن نعمان ـ واقع اللغة العربية في أجهزة الإعلام ( عرض تقويمي ) متاح على الرابط التالي :

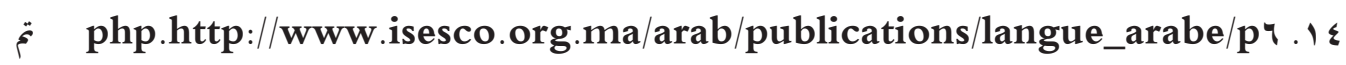

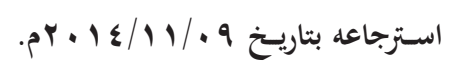

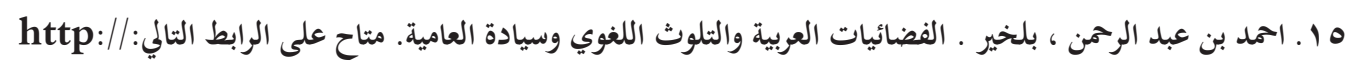

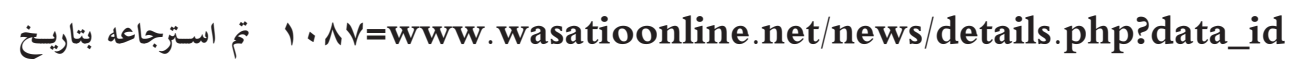

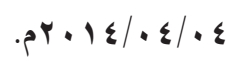

14 . نسرين ، عوطه ـ جدل استخدام العامية في الفضائيات اللبنانية، متاح على الرابط التالي: issue $\& V \cdot 10=\operatorname{article} \& Y \varepsilon=h t t p: / / w w w$. aaswat.com/details .asp?section . IV

$$
\begin{aligned}
& \vee Q Y,=\text { no }
\end{aligned}
$$

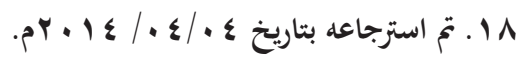

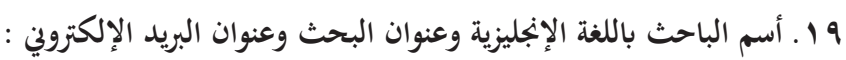

Nassir Salah Bouali . . .

Arabic Language and Violence of speech . Y I

In Arab broadcast Yr

nbouali@sharjah.ac.ae.rr

\begin{tabular}{l|c} 
& مجلة الباحث الاعلامي \\
\hline 191 & العدد (ro ( )
\end{tabular}

